\title{
Fascismo Olímpico. Sobre la relación entre espectáculo deportivo y propaganda de masas
}

\author{
Olympic Fascism. \\ The relationship between sports spectacles and mass propaganda
}

\author{
Antonio Méndez-Rubio. Universitat de València. España. \\ Antonio.Mendez@uv.es \\ $[\mathrm{CV}]$ \\ Javier Lizaga. Universitat de València. España. \\ jlizaga@hotmail.com \\ [CV]
}

\begin{abstract}
Cómo citar este artículo / Referencia normalizada
Méndez-Rubio, A. y Lizaga, J. (2020). Fascismo Olímpico. Sobre la relación entre espectáculo deportivo y propaganda de masas. Revista Latina de Comunicación Social, 75, 69-96. https://www.doi.org/10.4185/RLCS-2020-1417
\end{abstract}

\section{RESUMEN}

Frente a la reducción del fascismo a una época y en muchas ocasiones a un país (Alemania), se plantea si sus dispositivos culturales y estrategias comunicativas siguen vigentes, ya no como parte de un fascismo clásico, sino de equivalentes funcionales que conservan rasgos pragmáticos y condiciones sociales. Para ello, se analiza la construcción del imaginario fascista en el documental Olympia (1938) de Leni Riefenstahl, film referente del relato deportivo además de la propaganda nazi. Se plantea un análisis crítico en torno a los conceptos de líder y público. Se busca así establecer proyecciones a otras películas oficiales de Juegos Olímpicos modernos con la intención de cuestionar si existe un punto de contacto entre la cultura de masas, el fascismo y la propaganda. Queda identificada la superación de la relación mecánica entre el ideario y la imagen, las posibilidades propagandísticas de los códigos estéticos o documentales y la coincidencia de políticas comunicativas fascistas y contemporáneas.

PALABRAS CLAVE: Fascismo; Riefenstahl; propaganda; deporte; Olympia; cine.

\begin{abstract}
When limiting fascism to a time and often, a country (Germany), it is considered whether its cultural devices and communicational strategies are still valid, not as part of a classical fascism, but instead as functional equivalents that preserve pragmatic features and social conditions. To do this, there is an analysis of the fascist imagery in the documentary Olympia (1938) by Leni Riefenstahl, a film about the sports storytelling besides Nazi propaganda. There is a critical analysis about the concepts of leader and public. The aim is to stablish projections towards other official films of modern Olympic Games to question whether there is a point of contact between the mass culture, fascism and propaganda. The overcoming of the mechanic relationship between the ideas and the image is
\end{abstract}


identified, as well as the propaganda possibilities of aesthetical or documentary codes and the coincidence of fascist and contemporary communication policies.

KEYWORDS: Fascism; Riefenstahl; propaganda; sports; Olympia; cinema.

\section{CONTENIDO}

1. Introducción y metodología. 2. Delimitación teórica: la huella fascista. 3. Análisis y resultados: el espectáculo olímpico. 3.1 Líder. 3.2 Masa. 3.3 Atletas. 4. Conclusiones: Hacia la actualidad, desde el presente. 5 . Referencias bibliográficas.

\section{Introducción}

Conforme el fascismo aparece como un episodio histórico remoto, supuestamente limitado a la primera mitad del siglo XX, más viable y necesario se hace el análisis crítico de dicho fenómeno político e ideológico. La crisis económica, social y cultural que conmocionó el mapa internacional en el período 1920-1930 tuvo uno de sus más terribles epicentros en la Alemania nazi durante el gobierno de Adolf Hitler y el Partido Nacionalsocialista Obrero Alemán (1933-1945). El proyecto fascista clásico sería derrotado con el desenlace de la II Guerra Mundial, pero los dispositivos culturales y las herramientas comunicativas propias de la política fascista habían causado un impacto mundial que difícilmente podía borrarse del mapa. Algunos analistas, con posterioridad, han advertido de la "necesidad siempre actual de desgermanizar el nazismo" (Michaud 2009, p. 9). Esta necesidad trabaja contra la inercia ideológica que tiende a reducir el fenómeno fascista a unos años y naciones específicas, inercia que, a su vez, impediría entender aquellos elementos (como el poder de la propaganda, el espectáculo de masas o el racismo, entre otros) que el fascismo compartía con otros contextos sociocomunicativos y que, de hecho, han podido pervivir renovando sus fórmulas y métodos.

El filósofo Walter Benjamin, quien moriría en 1940 huyendo de la persecución fascista, indicó en un conocido texto que la "alienación autoinducida" tiene que ver con "la estetización de la política que propugna el fascismo" (2012, p. 85). Y en nota explicativa a ese mismo texto añade: "En desfiles gigantes y festivos, en descomunales asambleas, masivas celebraciones deportivas y, en fin, en la guerra, todo lo cual es hoy registrado por los aparatos de filmación, la masa se ve a sí misma cara a cara" (2012, p. 83). Pues bien, es esa relación pragmática entre fascismo, cultura de masa y espectáculo deportivo lo que destacaría como un signo actual de interrogación. Este artículo plantea un análisis de algunos elementos de esa producción cultural, en relación sobre todo con el espectáculo de masas, para entender mejor algunos aspectos de la comunicación deportiva contemporánea. Se trata de revisar críticamente, a nivel de textualidad audiovisual, una de las obras cinematográficas más complejas y vigentes que como herencia dejó el fascismo clásico:Olympia (1938) es el retrato fílmico que realizó Leni Riefenstahl de los Juegos Olímpicos de Berlín (1936) en una película todavía considerada uno de los mejores documentales de la historia (Downing 2012, p. 121). Se trata, pues, de resituar el imaginario fascista en esta producción cinematográfica poniendo el énfasis en las figuras del líder y el público para proponer hipótesis sobre cuáles de esas proyecciones siguen hoy vigentes. Al tratarse de una temática compleja y multidimensional se procura aquí delimitar y resaltar únicamente algunos aspectos de detalle que, desde un enfoque micro, puedan contribuir a iluminar una perspectiva más macro sobre las dinámicas comunicativas actuales.

\section{Delimitación teórica: La huella fascista}

Entre los más influyentes estudios del fascismo clásico se puede destacar al menos un argumento polémico transversal. Este argumento, expresado de una forma sintética por Z. Bauman (1998, p. 
15), plantearía "que tratemos el Holocausto como una prueba rara, aunque significativa y fiable, de las posibilidades ocultas de la sociedad moderna". Más provocativamente aún, señalaba Bauman en Modernidad y Holocausto (1998, pp. 14-15) que

es difícil calmar la angustia si pensamos que no ha desaparecido ninguna de las condiciones

sociales que hicieron que Auschwitz fuera posible, y no se ha tomado ninguna medida efectiva para evitar que esas posibilidades y principios generen catástrofes semejantes a la de Auschwitz.

Siguiendo a Bauman, la "singularidad y normalidad simultáneas del Holocausto" (1998, p. 123) se apoyaron en determinados mecanismos burocráticos, propagandísticos y técnicos que subsistieron de una forma renovada tras el nazismo debido a que su gestación había tenido que ver con el proyecto socializador de la modernidad occidental, industrial y colonial.

También en su ya clásico y prestigioso estudio Fascism: Comparison and Definition (original de 1980), Stanley G. Payne ha investigado en detalle tanto los antecedentes como los efectos históricos del fascismo para establecer que "el hitlerismo fue un producto sintomático del mundo moderno" (Payne 2014, p. 127). Payne argumenta cómo "las ideas filosóficas fascistas de hecho son un producto directo de aspectos de la Ilustración" (2014, p. 20) como, en efecto, habían desarrollado implícitamente ya otros teóricos críticos como T. W. Adorno y M. Horkheimer a la hora de conectar las dinámicas de control social totalitario con la emergencia de la Industria Cultural (Adorno / Horkheimer 2003). La conclusión de Payne (2014, p. 265) es sin duda inquietante: "En este sentido, la influencia del fascismo seguirá sintiéndose en el futuro, y también la sentirán algunos de los antifascistas formales más vociferantes". En esta dirección apuntaría asimismo R. O. Paxton en su más reciente The Anatomy of Fascism, un estudio pormenorizado, contextualizado y documentado sobre la genealogía y los matices del fenómeno fascista en el siglo XX. Para prepararse a responder a la pregunta decisiva "¿Qué es fascismo?" Paxton advierte:

Armados con el conocimiento histórico, debemos ser capaces de distinguir las imitaciones

desagradables pero aisladas de hoy, con sus cabezas afeitadas y sus tatuajes de la cruz gamada, de los equivalentes funcionales auténticos en la forma de una alianza fascistaconservadora madura. Prevenidos, debemos ser capaces de detectar lo auténtico cuando aparezca. (2005, p. 240)

En otras palabras, el presente mundial debería activar mecanismos de alerta para prevenir la reaparición ya no del fascismo en su modus operandi clásico y reconocido sino, más bien, bajo la forma de nuevos pero auténticos "equivalentes funcionales". Aunque sea una cuestión que no pueda ser del todo "abordable empíricamente" (Bauman 1998, p. 15) se puede deducir de aquí que la obsesión por la normalidad propia del fascismo (Arendt 2013, p. 46) haya calado precisamente como norma en desarrollos posteriores de la sociedad y la cultura contemporáneas. La huella (neo)fascista requiere, pues, un discernimiento atento de los factores que contribuyeron a la formación de una política y una cultura de devastación humana sin precedentes en tiempos de aguda crisis. Por eso mismo, siguiendo a Amery (2002, p. 157), "la primera premisa para su aplicación (o reaplicación) es una situación de crisis que incluya tanto la carestía material como la vivencia de una desorientación existencial". De nuevo se puede así observar por qué se siguen planteando debates en este sentido 
crítico: "Nuestra primera pregunta reza así: ¿es posible, o probable, una crisis hitleriana en el siglo XXI?”. (Amery 2002, p. 157)

Desde una perspectiva cultural y audiovisual, a partir del caso que representa el legado fílmico y fotográfico de Leni Riefenstahl, ha subrayado Susan Sontag en "Fascinante fascismo" (2007) que el imaginario fascista se alimenta de recursos como el espectáculo de propaganda, el culto a la belleza, la idealización física o el rechazo del intelecto. Sobre esta base, Sontag denuncia que todavía "estos ideales están vivos y conmueven a muchas personas" [lo que supone un reto para] "la capacidad moderna de detectar el anhelo fascista en nuestro medio" (2007, pp. 105-106). El diagnóstico de Sontag podría apoyarse en reflexiones previas del cineasta y escritor Pier Paolo Pasolini, quien en diversos pasajes de su obra, reflexiona sobre cómo el fascismo clásico habría ido transformándose en la segunda mitad del siglo XX hacia métodos ya no tanto político-militares como tecno-culturales. Este "nuevo poder" podría emblematizarse, según Pasolini, en la pregnancia cotidiana de la televisión como indicio de un "nuevo fascismo" aún más represivo que el fascismo precedente. En los términos que usara Pasolini (2009, p. 34) en torno a la década de 1970:

No cabe duda (a los resultados me remito) de que la televisión es más autoritaria y represiva

que ningún otro medio de información del mundo. A su lado, el periódico fascista y los

letreros mussolinianos pintados en las alquerías mueven a risa, como (con dolor) el arado

frente al tractor. El fascismo fue incapaz de arañar siquiera el alma del pueblo italiano; el

nuevo fascismo, a través de los nuevos medios de comunicación e información (sobre todo,

justamente, la televisión) no solo la ha arañado, sino que la ha lacerado, la ha violado.

Esta óptica crítica se confirmaría en la indicación que introduce Jean-Luc Godard en el guion de su film Adiós al lenguaje (2014): en los mismos años de ascenso histórico del fascismo comienzan las primeras pruebas con la tecnología televisiva. Se trataba del iconoscopio o tubo de rayos catódicos inventado por el ingeniero ruso Vladimir Zworykin. De ahí Godard pasa a una reflexión elemental: alguien derrotado por las armas puede vencer a su enemigo políticamente. O culturalmente: la cámara iconoscópica fue la cámara más usada para retransmisiones deportivas en Estados Unidos durante el período 1936-1946. En ese mismo período, los experimentos de J. Goebbels con la radio y el cine se convertían en referentes tanto de la persuasión masiva como de la mass communication research (Pizarroso 1990).

En diciembre de 1938 se escribe un capítulo del avance cultural de la propaganda nazi. En plena gira americana para presentar Olympia, Walt Disney se convierte en el único gran productor que recibe a Riefenstahl, boicoteada tras "la noche de los cristales rotos". El primer gran estudioso de este film olímpico, Cooper C. Graham, cita la incredulidad de Riefenstahl ante quienes no entendían el intercambio y detalla que Disney "tenía un gran sentimiento alemán. Recurría a menudo a las fabulas y los cuentos alemanes para encontrar inspiración" (Graham 2001, p. 223). El encuentro entre Riefenstahl y Disney, que llegará a ser investigado como simpatizante nazi (Vidal González 2006, p. 240), se produce a su vez en un marco de intereses industriales compartidos, tanto del interés por el cine de propaganda desde EEUU como por el cine de entretenimiento desde Alemania.

A pesar de ser indiscutible que la propaganda "alcanza sus cumbres más brillantes" (Pizarroso 2005, p. 56) con la política cultural nazi, no obstante, también se ha podido estudiar y constatar que "Goebbels decided that entertainment progamming was a vital part of the war effort" (Negus 1996, p. 
207). El interés por el cine como espectáculo de masa, que compartían tanto Riefenstahl como Disney, se presenta así como una metonimia del ascenso de aquello que más tarde se llamaría la sociedad del espectáculo (Debord 1999). En este sentido, la idea del totalitarismo como una tiranía basada en el aislamiento (Arendt 1987, p. 702) se puede articular con la hipótesis crítica que ve el aislamiento como inherente a la pragmática espectacular -en tanto, a decir de Debord (1999, p. 49), "el espectáculo reúne lo separado, pero lo reúne en cuanto separado".

En la segunda mitad del siglo XX, en suma, el fascismo espectacular podría haber experimentado una metamorfosis tecnológica y mediática gracias al impulso de la llamada sociedad de consumo. Es decir, capitalismo y fascismo habrían entrado durante el último siglo en un régimen de alianza mutua a escala global. Esta alianza estratégica habría permitido tanto al sistema capitalista como al proyecto fascista respaldarse recíprocamente en virtud de la implantación hegemónica de tipo soft, o smart, de todo un proceso de pantallización socialmente asimilado como "tratamiento de normalización" (Baceiredo 2016, p. 48). Se podría así afirmar razonablemente que "el Holocausto es ya, para bien o para mal, un producto de consumo" (Lozano 2010, p. 78), al tiempo que el fascismo de puede haber convertido en un enclave más del imaginario turístico, un tópico del cine comercial o un motivo de entretenimiento popular y masivo. Como se aprecia en la célebre y premiada La lista de Schindler (S. Spielberg, 1993), capitalismo y fascismo pueden incluso llegar a tener un rostro humano, esto es, "el hombre de negocios como héroe; el capitalismo puede proporcionar un sistema de salud universal y puede también dar un Schindler" (Lozano 2010, p. 101). Si, como señala con sarcasmo Paxton (2005, p. 243), "capitalismo y fascismo se hicieron compañeros de cama", entonces la expansión acelerada y globalizada del sistema capitalista en el siglo XXI podría darse en una "red compleja de interacción" (Paxton 2005, p. 31) donde política de masas, crisis socioeconómica y propaganda audiovisual funcionaran de forma conjunta. Desde luego, aun así no podría hablarse de fascismo en su sentido tradicional o clásico pero tal vez sí en el sentido de un nuevo fascismo o fascismo de baja intensidad (Méndez Rubio 2017) cuyos resortes estarían todavía por detectar y evaluar.

\section{Análisis y resultados: El espectáculo olímpico}

"El fascismo es, de todas las formas políticas, la más deliberadamente visual". Esta aseveración (Paxton 2005, p. 17) puede servir de hilo conductor para entrar a revisitar el caso específico de los espectáculos deportivos y su vigencia actual. Los Juegos Olímpicos de Berlín, sin ir más lejos, fueron el evento internacional más importante de la Alemania Nazi con 49 países y 4.069 atletas (Yagüe 1992, p. 199). Se calcula que se gastaron 32 millones de dólares frente a los 2,5 que costaron en 1932 los Juegos de los Ángeles (Yagüe 1992, p. 197), se construyeron por primera vez viviendas para los atletas, se amplió el estadio hasta los 100 mil espectadores, se estrenó el traslado de la antorcha olímpica... La película Olympia (1938) fue un encargo personal de Hitler a L. Riefenstahl, satisfecho el fuhrerpor el efecto psicológico y simbólico de una de las mayores obras de propaganda fílmica, dirigida también por Riefenstahl, El triunfo de la voluntad (Triumph des Willens, 1934). Olympia, por su parte, concreta y realiza la imagen que Alemania quería dar al resto de Europa y del mundo. Los violentos nunca necesitaron refutar argumentos contrarios, "preferían los métodos que concluían con la muerte más que en la persuasión, que difundían el terror, más que la convicción" (Gubern 2004, p. 251). La propaganda no son consignas para convencidos "pero puesto que los ya convencidos no necesitaban de tal propaganda, ésta se dirigía a los estratos no totalitarios de su población o a los países extranjeros no totalitarios" (Gubern 2004, p. 251).

El cine cumplía para el fascismo la función crucial de canalizar la energía colectiva hacia un "poder de despertar que era pensado como el poder de la verdad inmanente a la imagen" (Michaud 209, p. 158). La experiencia de las masas, como ya había insinuado Gustave Le Bon en su ensayo pionero Psicología de las masas (1895), demandaba una "reducción del pensamiento lingüístico a la imagen" 
(Michaud 2009, p. 295), por lo que las imágenes en movimiento actuaban como espacio de autorrealización proyectiva y efectiva de las necesidades afectivas de la multitud. La imagen fílmica se convertía así en espacio de producción y canalización de "pasiones movilizadoras" (Paxton 2005, p. 255). La imagen activaba así dispositivos de control de masa tendentes a sublimar tanto la crisis como la violencia del contexto social. La imagen, en fin, "modelo de la anticipación controlada y del engendramiento de lo mismo por lo mismo, era el lenguaje por excelencia del gobierno de los cuerpos" (Michaud 2009, p. 276). Y el cine se erigía entonces como un dispositivo de comunicación extremadamente funcional y poderoso. Los filmes de largometraje sobre las campañas bélicas y los noticieros semanales respaldaban de modo persistente esta necesidad de "propaganda cinematográfica directa" (Kracauer 1985, p. 257).

La era nazi, como advierte Eric Rentschler en su estudio sobre la vida postuma del cine nazi (The ministry of Illusion, original de 1996), representa para la mitología popular una época de terror, violencia y destrucción como una "inacabable película de terror en la cual el diablo y sus secuaces establecen la conquista del mundo" (Rentschler 2002, p. 7). Todo se desvanece, explica Rentschler, cuando uno se sienta frente a la pantalla. Si se recurre al compendio del sociólogo Gerd Albrecht se descubre que de las 1094 producciones del Tercer Reich, 941 eran producciones totalmente genéricas: 295 melodramas y biopics, 123 películas de aventuras y aproximadamente la mitad, 523, eran comedias y musicales (Rentschler 2002, p. 7). La revisión del cine nazi oscila entre la condena de este Gran Show Alemán del Terror (Rentschler 2002, p. 8) donde el entretenimiento sólo es un amplificador de la propaganda o, en el otro extremo, se habla del cine nazi desde la más absoluta fascinación, jugando con las palabras de Sontag. De hecho, muchos de los héroes pop de los 70 reivindicaron y recuperaron el legado de Riefenstahl: Francis Ford Coppola, Mick Jagger o Bryan Ferry (Seesslen 2013, p. 25). Hay también escenas que referencian a sus películas, por ejemplo, en Star Wars de George Lucas (Rentschler 2002, p. 6) termina con la misma imagen que Riefenstahl en Triumph des Willens (1934).

La fascinación cuestiona la inercia que acota al fascismo a un lugar, Alemania, y un siglo pasado. Pero al mismo tiempo es necesario deshacer también el tópico que habla del cine nazi como un panfleto anacrónico y propagandista. Sólo en las televisiones de la República Federal Alemana (la zona gobernada por los aliados) el 8\% de las películas emitidas en 1980 pertenecían al periodo nazi, 113 films que en 1989 se incrementaron hasta los 169 (Rentschler 2002, p. 4). Los datos y la admiración son sólo indicativos de la vigencia de todo un sistema y unas estrategias y mecanismos culturales. Entre la fascinación y el disgusto surge la complejidad de un sistema donde conviven ilusión y propaganda, es decir, donde "el cine de ficción y el de no ficción estaban en más de una ocasión perfectamente articulados para conseguir el efecto deseado" (Sandoval 2005, p. 100). Precisamente, el cine como una pieza más de esa cultura (escultura, arquitectura, radio, escenografías públicas, deporte...) que quería mecanizar la ilusión y que destierra la idea que preconcibe este sistema como un panfleto hagiográfico, insustancial que no merece la pena analizar. Pero, como plantea Rentschler, precisamente esa complejidad es otra muestra de actualidad y de proximidad a un modelo de masa específico:

La cultura de masas nazi emula y replica los patrones americanos de reconocimiento. Produjo una

industria del entretenimiento a un coste popular y de segunda mano: melodías de éxito, tendencias

de moda, revistas, brillantes comerciales, electrodomésticos para todos, audiencias masiva y

cinéfilos ansiosos que esperaban las novedades semanales de la cartelera. (2002, p. 22)

Uno de los grandes escenarios donde se puso en práctica esa cultura de masas nazi (usando el término de Rentschler) fueron los Juegos Olímpicos de Berlín, donde la complejidad de mensajes y 
la confluencia de imágenes son inevitables. Olympia fue el intento de relatarlo al mundo. Otra prueba frente a esas inercias que consideran la producción cultural nazi como un relato propio de una época y muy ideologizado es que estudiosos del fenómeno olímpico (Kruger 2003, p. 21) las consideran en cambio gracias a esta "propaganda planificada" como "las primeras olimpiadas de la era moderna". Ya en Triumph des Willens se habían vuelto un recurso dramatúrgico en la pantalla los "ornamentos espectaculares de masas excitadas" (Kracauer 1985, p. 272). En Olympiase daría además una sinergia decisiva: la convergencia del poder del cine con el poder del espectáculo deportivo para el imaginario fascista de masa. Es por tanto un caso singularmente ilustrativo. En la película de Riefenstahl, los elementos-clave o focos de énfasis tanto en el procedimiento de montaje como de diseño del mensaje político eran fundamentalmente tres: la figura de Hitler, la representación del público de masa, y la imagen de los deportistas.

\subsection{Líder}

Explica Michaud (2009, p. 10) que la representación visual de Hitler fue poco original y que lo que hizo más bien fue beber de las fuentes de la tradición europea, quizá también por eso plantea que se ha producido una encarnación en su persona del mal, una maldad felizmente derrotada después. Pone como ejemplo la asimilación del trabajo al arte reunidos en la expresión "trabajo creador" (2009, p. 10) que otorga al trabajo la capacidad, como el arte, de ser juzgado por sus resultados, ya no económicos, sino de generar objetos, de crear. Detrás de esta fantasía y este ejemplo, Michaud intenta desvelar el mito nazi y lo hace con referencia a dos campos, la religión y el arte, que continuamente constituyen un modelo para el nacional-socialismo:

- "El hombre de Estado también es un artista. Para él, el pueblo no es otra cosa que la piedra para el escultor. El Führer y la masa no plantea más problema que el pintor y el color”. Así se expresa Michael, el héroe de la novela de Goebbels titulada Combate por Berlín (1931) (citado en Michaud 2009, p. 13) y que quiere resumir cómo Hitler se convierte en el creador total, en el máximo artista. No se censura que el dictador manipule a la masa sino que, precisamente, su cometido es darle sentido a esa masa inerme. El Führer es el arquitecto o escultor de esta Alemania que al final es realmente la herramienta que le va a permitir realizar su verdadera obra de arte (universal). Ya no importan tanto los medios sino la culminación de ese propósito. Además, de ese modo, Hitler actualiza otro mito clásico, el que vinculaba el arte con la libertad, de forma que cada nuevo acto de violencia pareciera sólo una conquista más de la libertad $(2009$, p. 20).

- “Así como Jesús liberó a los hombres del pecado y del infierno, de igual manera Hitler salvó al pueblo alemán de la perdición. Jesús y Hitler fueron perseguidos pero mientras Jesús fue crucificado, Hitler ha sido promovido Canciller". Este discurso que dictaba un docente en una escuela comunal (recogido en Michaud 2009, p. 101), es mejor que muchos discursos y grandes alocuciones para resumir cómo el mito nazi se apropió de los esquemas de la religión. Sólo había que sustituir a Jesús por Hitler y ya no había que esperar sino que este nuevo dios realizara su obra. Su presencia suponía también que se iban a empezar a cumplir las esperanzas y anhelos de los nuevos creyentes. Alemania podía ser como cada individuo anhelase que fuera. En ese primer estado no había límites sino fe e ilusión. "El partido es Hitler, pero Hitler es Alemania como Alemania es Hitler", como decía Rudolf Hess en Nuremberg (2009, p. 63) en una identificación que recuerda al evangelio según San Juan.

Sin embargo, este ideal de Führer-mesías como creador total encuentra en Olympia una representación diferente y tal vez complementaria. Hitler no era sólo el primer actor (como autor en sentido máximo, como creador) y la encarnación de una nueva Alemania, necesariamente Hitler era también padre, amigo y compañero. Se propone en la película de Riefenstahl tener en cuenta el desarrollo de una contrafigura como concepto que permite descargar la violencia y el peso de la 
autoridad que implica el doble mito religioso y artístico. Frente a ese Führer que tiene que aplicar la violencia como creador todopoderoso en pos de la obra de arte salvífica, final, lo que Riefenstahl presenta es un Führer necesariamente cercano y humano, imperfecto y sufridor.

El estadio de Berlín ocupado para inaugurar los Juegos Olímpicos con 100 mil espectadores era como una gran catedral o la materia prima para una gran obra de arte. Una celebración multitudinaria era la base del mensaje, claro está, pero no hay que olvidar que no se podía confiar sólo en los testigos. Había que difundir semejante espectáculo y para ello se concibe la película de Riefenstahl. No hay que olvidar tampoco que los alemanes ya están convencidos y, si la escenografía sirve para abrumar a los asistentes, el mensaje fílmico que se elabore con ella debe servir en cambio para convencer al resto del mundo. "Olympia" es una película configurada para la propaganda internacional, por eso es tan interesante también analizar su mirada diferenciada frente a la que se daba dentro de Alemania y tener en cuenta los matices que aporta a esa construcción del mito nazi. Graham (2001, p. 46) cita al director de prensa de Riefenstahl, quien expone que si la cineasta mostró a Hitler como un héroe en Triumph des willens, ahora en Olympia quería sin embargo mostrarle como:

the private man, the spectator who modestly stepped back before the heroes of the hour, the

athletes. At the important victories, he was to applaud: his pleasure would signify more than

an Olympic victory. A whole string of cameramen was specially trained to take candid shots

of his most natural poses.

El Führer aparece en 8 secuencias diferentes de las 20 en que se divide la primera parte de Olympia y no aparece ni en una sola imagen de la segunda parte, "Juventud olímpica". Cada aparición supone como mínimo un conjunto de entre tres y cinco planos que constituyen una micro-secuencia. En el preámbulo se contabilizan tres escenas: Hitler que observa y abre con su saludo el desfile, Hitler que se golpea en el pecho cuando ante los deportistas alemanes y Hitler que pronuncia el discurso inaugural. Por tanto, la primera característica es la austeridad: en 190 minutos, que dura en total Olympia, Hitler aparece sólo unos pocos minutos y en la segunda parte desaparece. Aun así ese espacio ya basta para configurar al líder como personaje principal pues ningún otro atleta o personaje iguala su tiempo en pantalla. Lo primero en el preámbulo es establecer el liderazgo del Führer. Sus primeras imágenes son las del jefe del Estado que inaugura los Juegos y la referencia al que saludan los atletas. Hitler es Alemania, Alemania es Hitler. El saludo y su discurso establecen su marco o referente político. El líder nazi se muestra entonces rotundo, solemne, sin emociones.
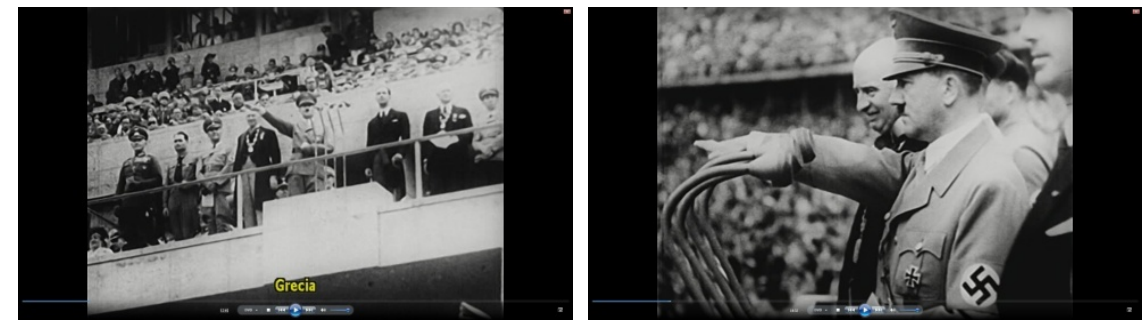

Figura 1: imágenes de Hitler en el palco durante el prólogo.

Dos anécdotas ilustran bien hasta qué punto es compleja cada una de las apariciones de Hitler. Por una parte, un cámara estaba dedicado específicamente a registrar cada uno de sus movimientos. De hecho, se conserva su carta de petición de la distinción olímpica por sus grandes resultados entre los que enumera "haber mostrado entusiasta y eufórico en determinados momentos al Führer" y a otras 
personalidades (Graham 2001, p. 46). Esa pista confirma que había una planificación para registrar cuidadosamente las reacciones de Hitler. El hecho de tener un cámara destinado al palco implica que todas las ocasiones en que el fuhrer asistió quedaron registradas. Por lo que la limitada presencia de Hitler en la película (no aparece en toda la segunda parte) es algo paradójicamente buscado. Se podían haber usado planos de unas pruebas y falsear su presencia en otras, planos tenían de sobras porque había un cámara sólo con él. La investigación histórica demuestra, sin embargo, que a la mínima incluso se recortaron las apariciones: la propia Riefenstahl elaboró una versión cortando todas las apariciones de Hitler cuando la censura y la crítica impidieron la comercialización del film en Estados Unidos (Graham 2001, p. 195).

$\mathrm{Al}$ respecto se puede aportar una segunda anécdota que relata Yagüe (1992, p. 199) (y confirman otros autores como Downing 2012, p. 82-83) sobre la primera victoria alemana en las pruebas olímpicas. El domingo 2 de agosto un calendario bien calculado hizo que el primer campeón olímpico fuese alemán. El policía Hans Woelke, quien esa misma noche sería ascendido a teniente por sus servicios a la patria, lanzó el peso a 16,20 metros y los gritos de "Heil! Heil!" atronaron en el estadio. Woelke es recibido junto a los otros vencedores de la jornada en el palco por Hitler. Este detalle, como puntualiza Yagüe (1992, p. 200), es el origen de una leyenda "que no se ajusta exactamente a la realidad". Tampoco Hitler recibiría al día siguiente a Jesse Owens, pero no lo hará no por motivos racistas (que nunca ocultó Hitler), sino porque el Conde Baillet-Latour (presidente del IOC) le advirtió de que su gesto no era protocolario y si recibía a unos vencedores habría de recibir después a todos los que siguieran. Así que todo apunta a que Hitler sólo asistió a los Juegos cuando se podía dar una victoria alemana y de esas ocasiones da cuenta la película. Ese primer día también se produjo la triple victoria finlandesa en los 10.000 metros que, aunque en la película de Riefenstahl aparece casi una hora después de la victoria de Woelke, se produjo en la misma mañana. Por la tarde, para la final de altura, sin alemanes y con dos americanos como favoritos, Hitler se marchó.

Lo que debe tenerse en cuenta, sabiendo que un cámara registraba cada movimiento, es, en cambio, la construcción de la imagen de Hitler que se elige. Superado el prólogo, hay otros cinco bloques en los que tiene apariciones. Son las pruebas de martillo, lanzamiento de peso, salto de longitud, 10.000 metros y relevos femeninos. Lo que sí es imputable directamente a la película en cuanto a la imagen del líder es que sus apariciones están debidamente espaciadas y ordenadas para que, al mismo tiempo, no resulten redundantes o demasiado repetitivas. Hitler tarda en aparecer 11 minutos (prueba de martillo) desaparece otros 16 minutos (peso) de nuevo otros 7 minutos (salto de longitud) y se ausenta otros 20 minutos (hasta los $10.000 \mathrm{~m}$ y los relevos). De este modo, su última aparición es en la prueba número 18 de una primera parte donde quedan recogidas 20 disciplinas atléticas. No sólo hay cierto equilibrio en esas ausencias sino que la presencia del Führer se extiende desde el minuto 12, con su primera aparición en el desfile, al minuto 1:27:25 cuando se cierra la prueba de relevos femeninos y apenas quedan 15 minutos de película.

Hay que subrayar también los matices que implican las diversas apariciones de Hitler. Por ejemplo:
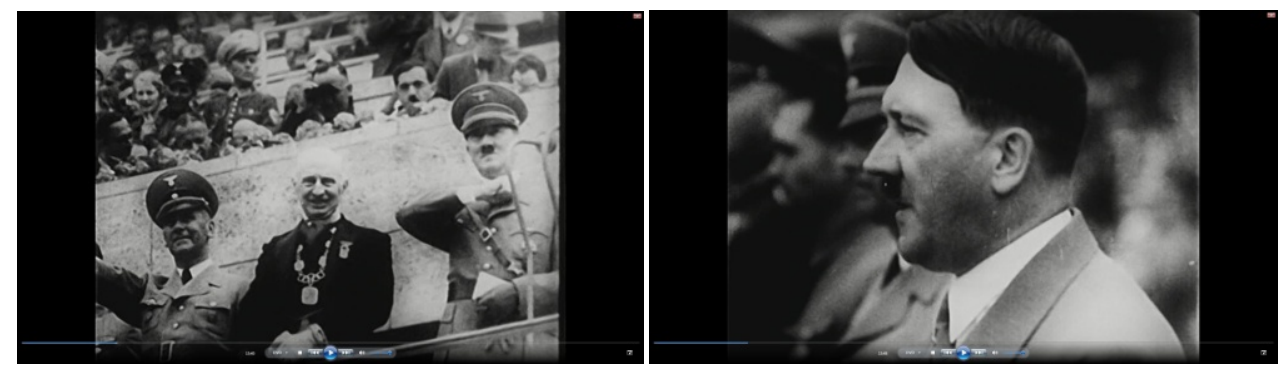

Figura 2: imágenes de Hitler durante el desfile de la selección de deportistas alemanes con su puño en el pecho y en el discurso inaugural con la cabeza descubierta. 


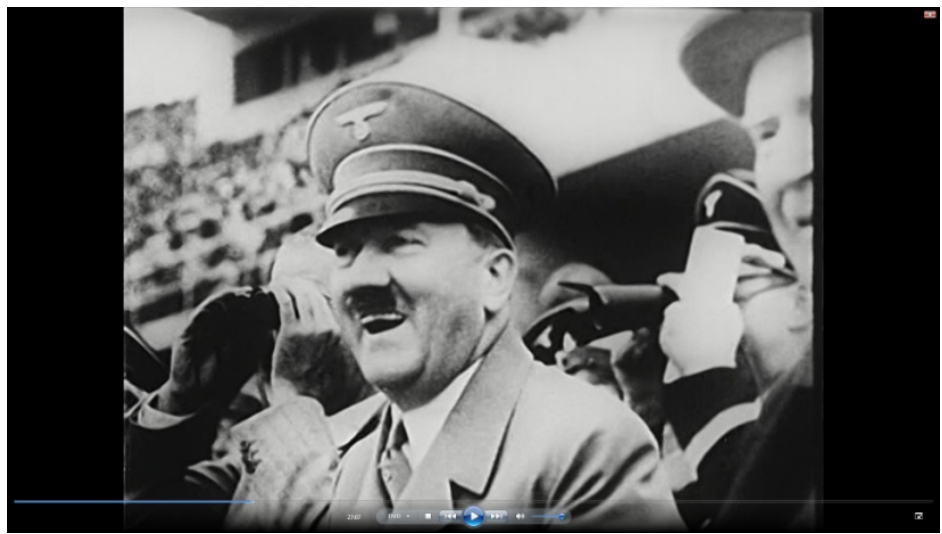

Figura 3: imágenes de Hitler durante las pruebas de lanzamiento de martillo cuando Alemania gana el oro. Hitler sonríe.

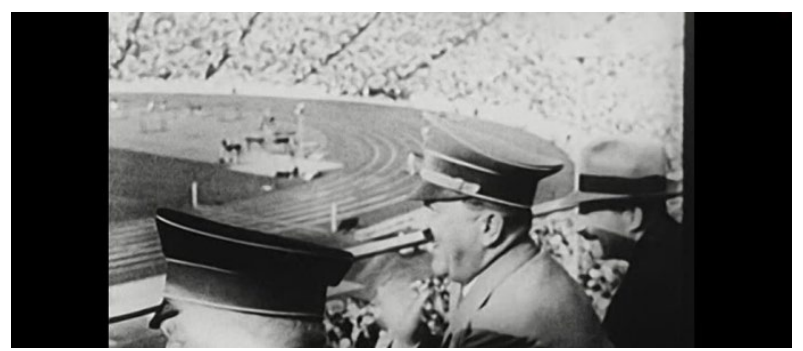

Figura 4: Hitler durante la prueba de lanzamiento de peso (secuencia 8). Vence Alemania y su líder aplaude con ahínco.

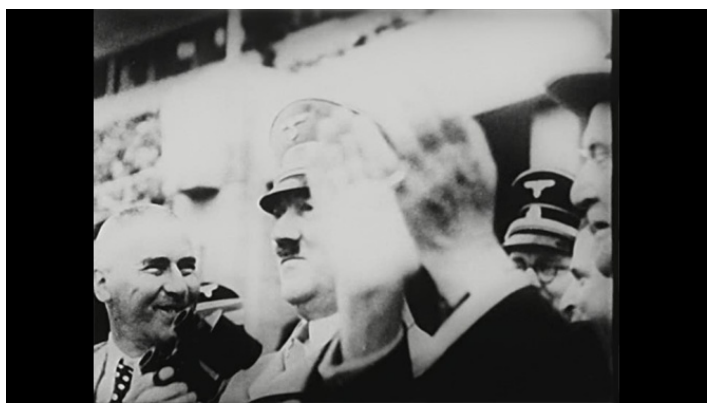

Figura 5: durante la prueba de salto de longitud (secuencia 11) la cámara realiza una panorámica desde la bandera a Hitler. La prueba la gana Estados Unidos, Alemania es medalla de plata. Hitler muestra su orgullo después del salto del alemán.

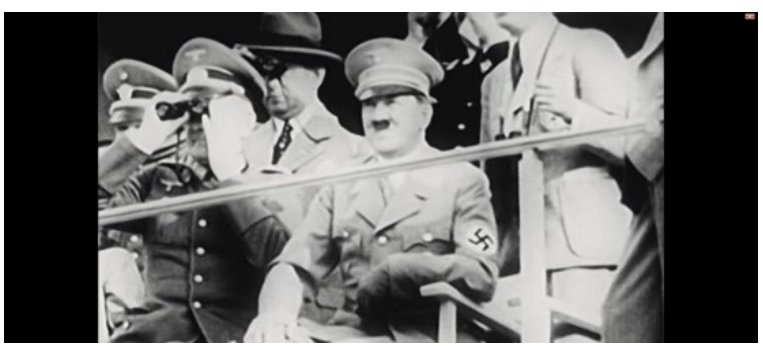

Figura 6: los 10.000m, la prueba número 16. Hitler se muestra nervioso cuando Finlandia copa el medallero. 
Aunque se recuerda su referencialidad cuando la cámara realiza una panorámica de la bandera a Hitler antes de comenzar la prueba de salto de longitud, el Führer se despoja aquí de su formalidad gestual. En estos planos se aprecia un Hitler sin gorra militar, riéndose abiertamente, aplaudiendo sin comedimiento medio de pie, o serio y defraudado. La gama de emociones sitúan a Hitler cercano al espectador, como un individuo más. La diferencia es que ahora el dictador tiene emociones. Eso también hace que sus apariciones tengan mayor peso. Por mucho que Owens sea el triunfador de los Juegos y le veamos ganar varias medallas, no puede actuar, gesticular, ni situarse frente a los espectadores como protagonista central de la pantalla.

Una escena permite detallar la distancia del Hitler máximo artista-mesías de Alemania al Hitlerpadre que muestra Olympia. Es la prueba de relevos femeninos donde Alemania era la absoluta favorita después de que en las eliminatorias previas sus atletas hubieran ya batido el récord del mundo. La prueba apenas dura dos minutos y son cuatro los insertos de Hitler. Los atletas se sitúan en sus posiciones y Hitler aparece charlando amistosamente con su compañero de palco (que, por cierto, no será la misma persona dos minutos después cuando al abrirse el plano al final de la prueba veamos a Goebbels a su lado). Acto seguido vemos a Hitler inquieto después de que una salida en falso haya obligado a volver a comenzar. El tercer plano aparece justo después del pistoletazo de salida. La figura del Führer se incorpora como un resorte, tan rápidamente que se escapa de plano (quizá por esos detalles no acabaron de condecorar al cámara) y rápidamente vemos a un Hitler nervioso, tenso, expectante y pendiente de las corredoras alemanas. La carrera no se interrumpe y vemos a continuación cómo en el tercer relevo las atletas alemanas cometen un error y el relevo cae al suelo. Han perdido. Ganan las corredoras estadounidenses e inmediatamente se nos ofrece la escena de un Hitler que se lamenta y pega un puñetazo sobre su regazo.
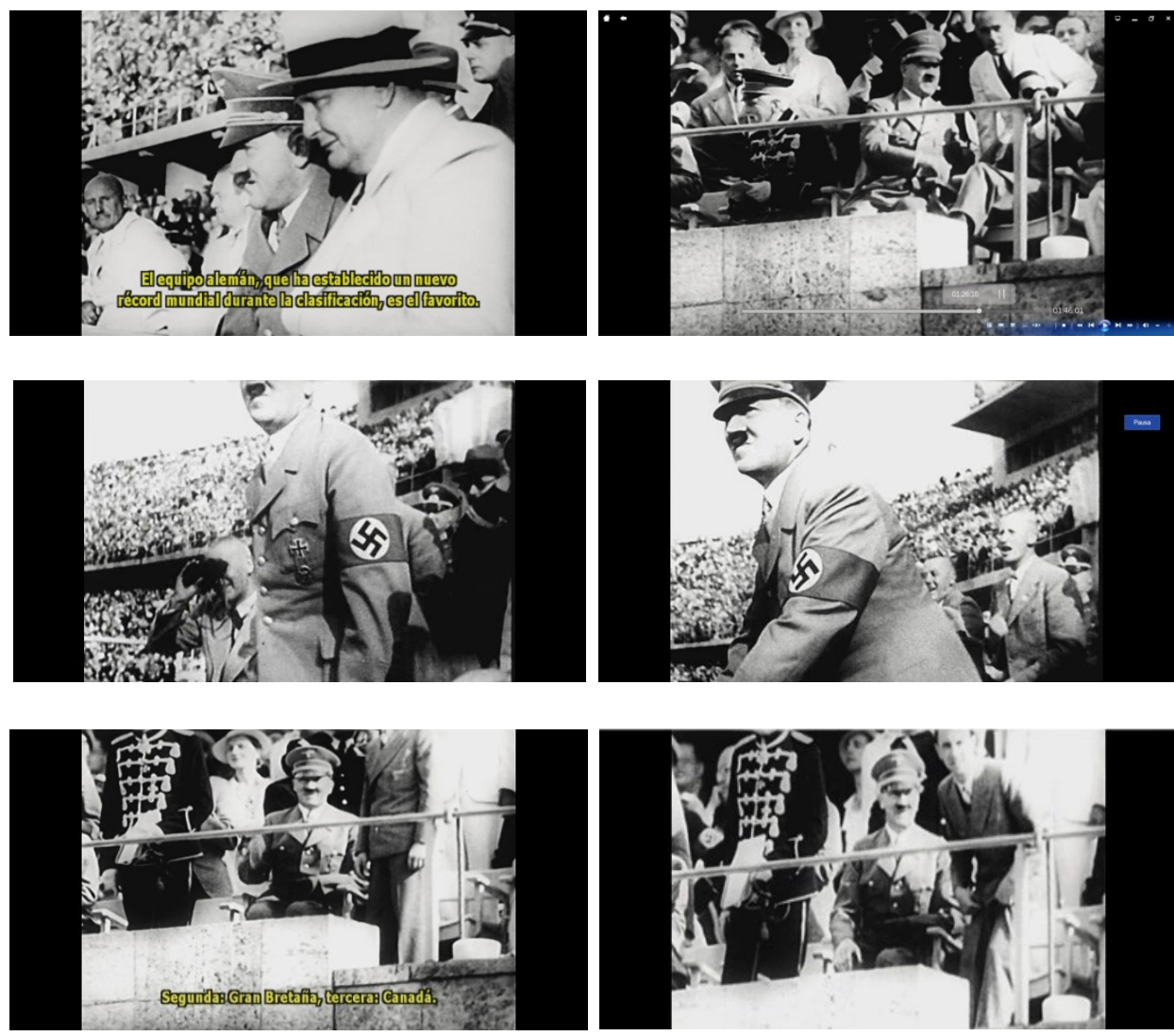

Figura 7: en la prueba de relevos femeninos (secuencia 18) Hitler sufre y se emociona con lo que iba a ser una victoria alemana hasta que la corredora alemana pierde el relevo (imágenes ordenadas por estricto orden de aparición). 
Riefenstahl no sólo muestra a Hitler como una figura no amenazante (Graham 2001, p. 46) sino que incluso humaniza su figura. En el párrafo anterior se ha descrito la variedad de matices, emociones o sentimientos que expresa el líder nazi y que le convierten además en el personaje más complejo de la película. Se puede discutir si Jesse Owens al aparecer en dos pruebas no obtiene más espacio como tiempo físico, pero es cierto que la mayor parte del tiempo Owens está corriendo o saltando mientras que Hitler pasa el tiempo que le dedica la cámara en plena actuación. Pero si se ha elegido esta secuencia es porque, sin duda, a nadie le pasa inadvertido que lo que muestra es un Hitler perdedor.

Aunque lo previsto es que ganasen las relevistas alemanas, su accidental error acaba en decepción para el público y, por supuesto, así lo muestra Hitler casi como una parte más de ese público masivo. Desde luego mediante el montaje se podrían haber evitado estas imágenes de un Führer que se lamenta, contrariado, y que a priori no parece una imagen muy congruente con un Hitler que encarna al Guía o Mesías de la nueva Alemania. Sin embargo, precisamente que se elija mantener esta secuencia permite sostener que, por encima de ese mito, en este mensaje prevalece la intención de mostrar a un Hitler humano y cercano. Una película dirigida a mostrar al mundo cómo es Alemania no está dejando al arbitrio de la realidad este pequeño detalle, sin duda relevante, como no se descuida ningún otro (hay pruebas olímpicas completas que se vuelven a grabar para generar un efecto concreto y muchas que se suprimen) sino que esta mostración de un Hitler próximo, terrenal, es también parte de ese mito. No sólo es una cuestión de código nacionalista (Hitler siempre ligado a los deportistas alemanes) sino que incluso se puede leer como un apoyo al pueblo, a los también derrotados en los momentos de la amarga derrota deportiva (y política).

En palabras de Downing (2012, p. 78):

Pero específicamente en cuanto al número de planos, la versión Inglesa de la película no

eleva a Hitler por encima de la importancia de ningún líder estatal en la proclamación de unos

Juegos Olímpicos como inaugurados. Un director menor le hubiera dedicado mayor número

de tomas a Hitler. Pero el enfoque sutil de Riefenstahl incluso deja al espectador con la

sensación de Hitler que preside, por encima de pruebas concretas. Incluso cuando no es visto, su presencia es sentida.

La destreza cinematográfica de Riefenstahl, como indica Downing, consiste en que no necesita muchos planos o una simple redundancia, que sería delatora, para convertir a Hitler en una referencia por encima de los Juegos. Por una parte, parece que simplemente se le sitúa como público en las pruebas a las que asistió. Por otra parte, además de ese tono documental, las imágenes delatan una intencionalidad y ese plan previo que evidencia también las palabras del camarógrafo que en exclusiva tenía que recoger las escenas de Hitler. Olympia convierte a Hitler, en su primera parte, en un actor principal, pero no en una figura quasi-divina.

Esta caracterización incluso permite entender que no aparezca en la segunda parte del film, sencillamente porque no asistió a esas pruebas, es cierto, pero quizá también porque ya no es necesario redundar en un mensaje que ha quedado claro. En esa segunda parte, como establece Downing (2012, p. 78), Hitler se convierte en un fantasma cuya presencia se (pre)siente. Hitler es protagonista no sólo en los Juegos sino en la película de Riefenstahl. Ya no hace falta evidenciar que Hitler está ahí, su presencia se siente en cada mirada al cielo o cada saludo nazi, y esto gracias a la pregnancia que esta presencia adquiere en la parte primera (parte clave para emplazar la mirada del 
espectador en el relato). Lo que sorprende es que sea un Hitler emocional y cercano. Pero esa distancia entre una realidad violenta y una película amable es la clave de propaganda para desactivar la imagen del Hitler agresivo y amenazante que teme Europa.
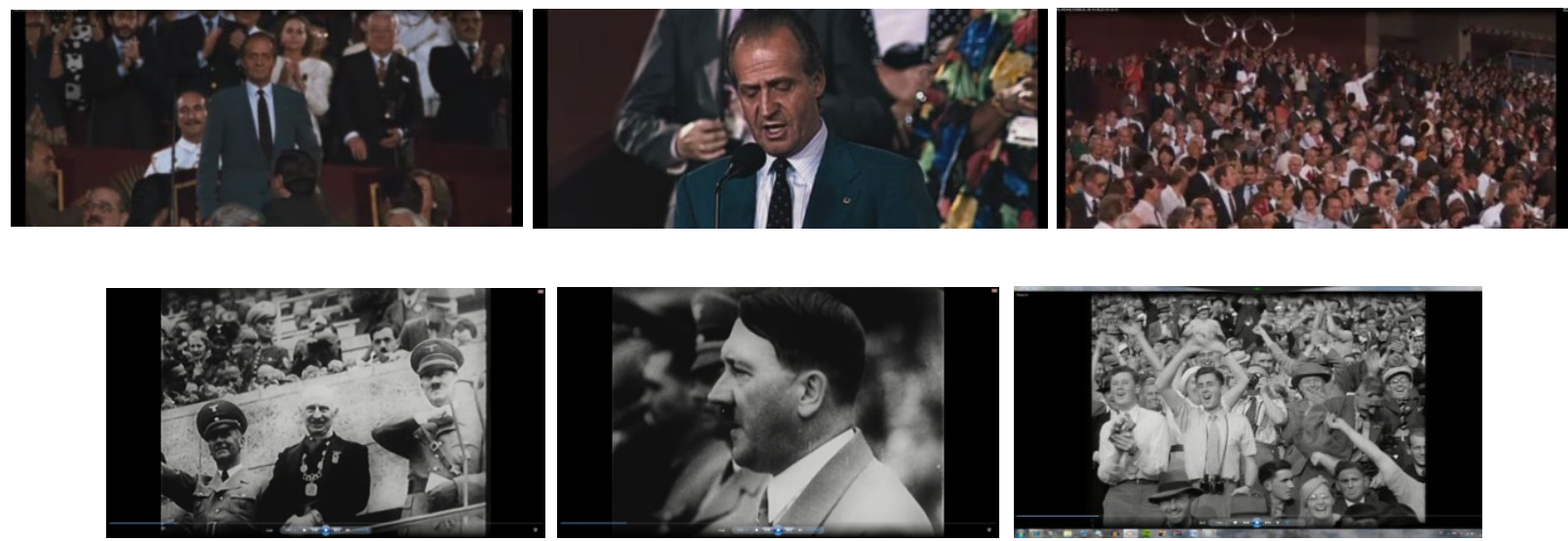

Figura 8: (de izquierda a derecha y de arriba abajo), imágenes de Marathon (1992) de Carlos Saura.

La primera imagen corresponde al parón que hace el rey ante el aplauso improvisado del público cuando le dan paso para leer el discurso (segunda imagen) ante la aclamación de un estadio multitudinario (tercera imagen). Se comparan con la imagen de Hitler que se golpea el pecho durante

el desfile de naciones, después del cual leerá el discurso (quinta imagen) ante la aclamación de la multitud (sexta imagen).

Políticamente hablando, no puede equiparse a Hitler con el rey Juan Carlos, pero esta secuencia de imágenes compara icónicamente la puesta en escena del discurso del fuhrer en Olympia (1938) y la apertura con las palabras del monarca de los Juegos de Barcelona relatado por la película oficial de esos Juegos, Marathon (1992), dirigida por Carlos Saura. 60 años después el referente político, en este caso el rey, vuelve a ser el único con tantas apariciones (tres) como el referente deportivo (Carl Lewis le iguala con otras tres escenas) y, otra coincidencia, también sus planos sirven para abrir la cinta. Es sólo un ejemplo del papel de poder simbólico que juega la familia real. Marathon volverá a mostrar al rey, precisamente, cuando la selección española gana el oro por una disciplina tan popular como el fútbol, para subrayar esa comunión entre el público y el monarca. No será la única referencia, no obstante, a la familia real: a pesar de no hacer seguimiento ninguno a la prueba de vela, se aprovecha un collage musical para mostrar al entonces príncipe Felipe practicando esta disciplina y la cámara recogerá también su papel como abanderado. La exhibición simbólica del poder es uno de esos rasgos que los relatos deportivos asumen desde Olympia. Uno de los dos manuales monográficos sobre la película de Riefenstahl, el estudio de T. Downing, ya adelanta que Riefenstahl "captura el potente impacto emocional de la Ceremonia de Apertura. Pero meramente en términos de número de planos, la versión inglesa de la película no eleva a Hitler por encima de la importancia de ningún otro dirigente nacional proclamando inaugurados unos Juegos" (Downing 2012, p. 78). La carga simbólica de Hitler y su demonización posterior han evitado durante años estos paralelismos y análisis.

En perspectiva, la primera clave que deja Olympia es que cualquier otro líder político, democrático o no, que ha seguido a Hitler en la presidencia de unos Juegos recibe mayor detalle y mayor espacio en cualquiera de las retransmisiones que se ofrecen. La pregunta incluso es si no se debería revisar la actualidad del mito nazi con esta reformulación. Porque ya no se trata sólo de un mesías que identifica su destino con el de toda una nación. El líder fascista es la personalización de las ilusiones de su pueblo, la personificación de su logro, también quien debe conducir y moldear pero, al mismo tiempo, es uno de ellos. No debe pensarse en un líder elevado, grandilocuente y más capacitado que 
la masa sino todo lo contrario. Alguien que evidencia sus errores, incluso su torpeza, alguien que se equivoca, se emociona o se frustra como ellos. En este sentido, el líder interviene con las mismas características de lo que comúnmente se conoce en la industria cultural como star system.

Puede servir en este punto la referencia a P. Sloterdijk (2002) quien considera el fascismo en relación directa con la experiencia de masas y, en concreto, mediante analogías con la religión (2002, p. 23). La novedad es que introduce, sobre todo, una voluntad de ensalzar al héroe y se remite al ideólogoThomas Carlyle. Sloterdijk (2002, p. 23) da dos características: la idealización o glorificación sin atender a las propiedades reales del objeto, por un lado, $\mathrm{y}$, por otro, hasta qué punto esa identificación implica también una regresión psíquica de los espectadores. Así, el papel del Fuhrer no destaca por sus extraordinarias aptitudes sino por su "vulgaridad" (2002, p. 25). Hitler abandona por un momento su papel de guía o héroe para convertirse en portavoz. Lo que parece una adaptación y moderación del mensaje propagandístico del Führer (de la superioridad basada por ejemplo en la raza, al delegado que recoge y sabe interpretar la voluntad del pueblo) es un mensaje más complejo y más actual. En ambos casos es la misma estrategia de autoproclamarse depositario de la voluntad popular (por decreto divino o por intuición) pero el segundo planteamiento es mucho más moderado, más, por decirlo así, democrático. La pregunta es si esa adaptación del mito fascista de cara al mundo no ha acabado siendo la línea de modernización liberal del mito que le ha permitido llegar hasta nuestros días.

Cuatro décadas más tarde Susan Sontag volvería sobre el mito nazi para analizar la producción fotográfica de la desnazificada Riefenstahl. En su ensayo "Fascinante fascismo", escrito en 1974, Sontag argumenta (2007, p. 103):

Para un público alemán poco refinado, el atractivo del arte nazi pudo consistir en que era

sencillo, figurativo, emocional; no intelectual; un alivio de las exigentes complejidades del

arte moderno. Para un público más refinado, el atractivo puede deberse, en parte, a esa avidez

con que hoy se están descubriendo todos los estilos del pasado, especialmente los más

criticados.

El ensayo de Sontag sobre la serie fotográfica de Riefenstahl titulada Los nubaes pionero a la hora dellamar la atención sobre el atractivo simbólico, magnético, que ejerce el fascismo para las nuevas generaciones. Se trata de un mensaje simplista, directo, que Sontag (2007, p. 111) llega a comparar con una forma de Pop Artsuplementada con el gancho de un arte maldito, criticado y prohibido. Sontag denuncia la vigencia del mensaje fascista pero también su complejidad de matices. En la película de Riefenstahl se exhiben esvásticas, muchedumbres alentando a Hitler, el saludo fascista... pero también un líder circunspecto, humanizado, de modo que el mensaje parece contener sus medidos contrapuntos. Hitler es también padre, espectador defraudado, entusiasta seguidor... Es como si, al mismo tiempo, unas escenas desmontaran o matizaran a las otras. Unas imágenes sirven de coartada a las otras. La voluntad documental dialoga así con la voluntad propagandística.

\subsection{Masa}

Si Hitler o los soldados son personajes principales del espectáculo olímpico, por espacio, función y tiempo en pantalla también lo es el público. Ese público al que vemos animar, cantar, levantarse, reírse y que continuamente da la réplica a lo que ocurre en el estadio. El público funciona como un representante diegético de los espectadores en las salas de cine, de ahí su importancia estratégica en 
la narración y el montaje. Hay que empezar diciendo que las imágenes de público que asiste al estadio presentan variedad de tamaños de planos $\mathrm{y}$, sobre todo, una gran abundancia. Esta proliferación de imágenes del público crea una trama simbólica que dota de un sustento colectivo y social al mensaje y el significado del film. Por ejemplo, si la imagen de detalle, como un martillo que acaba de ser lanzado o la cara de un ciclista, permiten avanzar la escena (por elipsis), el público lo que hace es ralentizar la acción, el momento de la victoria. Sin este público-masa la imagen de los Juegos Olímpicos de Berlín no sería la misma, ni la imagen del fascismo tampoco.

El público en Olympia es, sobre todo, un espejo. Un espejo doble: refleja los acontecimientos deportivos en directo, y a la vez anticipa el efecto que se espera conseguir con la recepción de la película por parte de cualquier espectador. Los asistentes nos traducen y transmiten lo que está pasando en el campo. Lo que sucede es que al verbalizar o mostrar una reacción se convierte en un modelo también de reacción que se nos ofrece. Es decir, si un primer momento los espectadores en el estadio muestran la felicidad porque ha ganado su atleta, al mismo tiempo funcionan como propuesta para que sintamos lo que está sucediendo de modo diferido a través de ellos y nos alegremos, nos emocionemos, compartamos esa alegría por una u otra victoria.
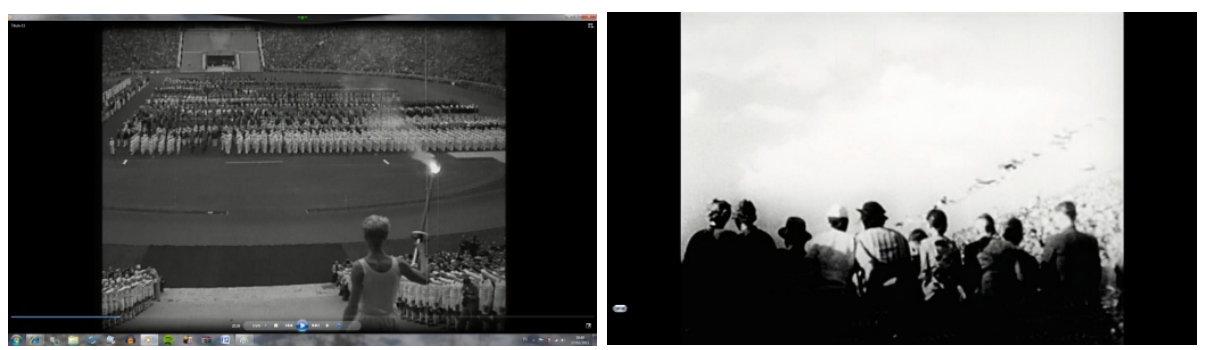

Figura 9: imágenes subjetivas en el prólogo y prueba de remo.

Esa propuesta para convertirnos en público no sólo se da en el mismo momento en que la antorcha llega al estadio (cuando la cámara nos invita a ser quienes la ven llegar hasta allí) sino que se repite una y otra vez. Tras la prueba de remo, ya en la segunda parte de la película, una gran panorámica nos devuelve al estadio y nos sitúa de nuevo (como se aprecia en la figura 9) detrás del público. Llama la atención que ya se plantea la posición subjetiva, implicativa: la cámara nos sitúa a la altura del público o detrás del portador de la antorcha, como si estuviésemos no sólo identificados con el público sino en la misma grada.

Ese grado de identidad que se busca entre el deportista y el público (y entre el público y el espectador) está presente también en un detalle que puede no advertirse al principio, pero que se repite una y otra vez: el público que anima al participante suele compartir con él nacionalidad. No sólo se trata de una identificación o una traducción de lo que ocurre subjetivamente a través de los espectadores sino que se busca, en el plano ideológico, de una competición entre naciones que también queda trasladada al público (y a los espectadores delante de la pantalla). Se trata de un nacionalismo traducido al mismo tiempo al deporte y al cine. Puede que esta implicación subjetiva e ideológica de la mirada espectatorial sea lo que lleva a Sontag a declarar que el recurso fascista al "drama del jefe y del coro" impulsa un "fervor político" que aleja a Riefenstahl del cinema verité y la instala de pleno en los registros del cine de propaganda (Sontag 2007, p. 90). Este fervor se aprecia en Olympia como un topos o lugar común del espectáculo filmado: 

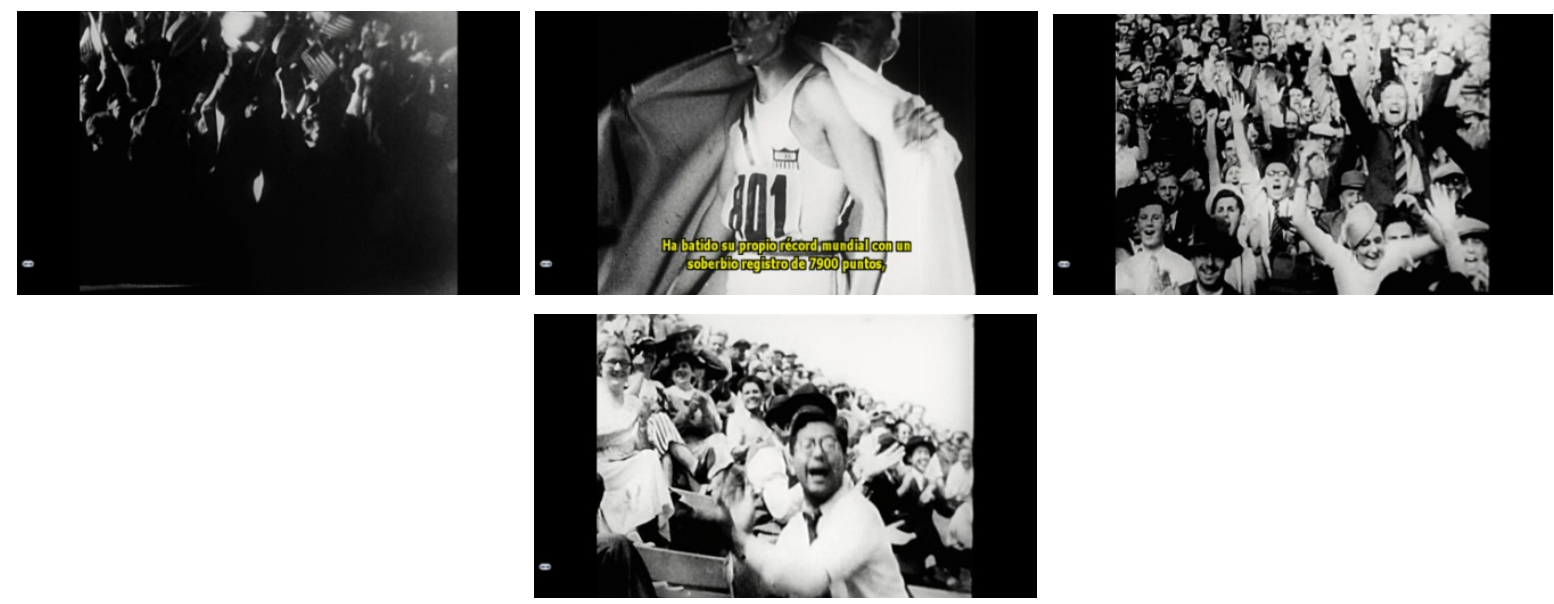

Figura 10: identificación del público con elementos nacionales como banderas o atletas.

Los ejemplos de planos que pueden señalarse son abundantes pero pueden verse ondear las banderas norteamericanas entre el público, algo que nos permite así identificar que se trata de quienes están animando a Morris tras ganar el decatlón. Lo mismo ocurre ante el gol del empate de Austria en el partido de fútbol o con los japoneses que gritan y saltan de júbilo ante la victoria del nadador japonés. La propaganda nacionalista, vista así, no se limita al nacional-socialismo alemán sino que, desde la perspectiva de éste que se subraya en la parte inicial del film, invita o acoge a otros nacionalismos para que se sientan integrados en el mismo espacio de representación visual, en el imaginario colectivo.

El público se convierte también en un coro de animación, en una especie de depósito o motor de energía celebratoria. Si a los atletas les queda reservada la gloria, ensalzados mediante la iluminación, los primeros planos o la música de la banda sonora, al público le corresponde el papel crucial de convocarnos, interpelarnos, emocionarnos, incluso hacernos reír, etc. Olympia también muestra pinceladas de humor. Por ejemplo, durante la prueba de lanzamiento de peso, la participación del público es aún más directa. Aquí se observa que una espectadora imita simpáticamente a un lanzador de quien el locutor ya ha dicho que el peso en sus manos "parece un guisante". Cada individuo que es miembro del público da rostro humano, concreto, a la potencia generalizada de la masa convocada dentro y fuera del estadio para celebrar el acontecimiento deportivo y político que son las Olimpiadas. Desde esta perspectiva, parece claro que esta fórmula de representación audiovisual del público deportivo se ha generalizado en las últimas décadas para retransmisiones televisivas y cinematográficas aparentemente diversas. Esta apreciación parecería dar la razón al argumento de W. Benjamin: "La masa es una matrix de la que surge actualmente renacida toda la conducta habitual. (...) La cantidad se ha vuelto cualidad. Las grandes masas de participantes han generado una clase diferente de participación" (Benjamin 2012, p. 81).
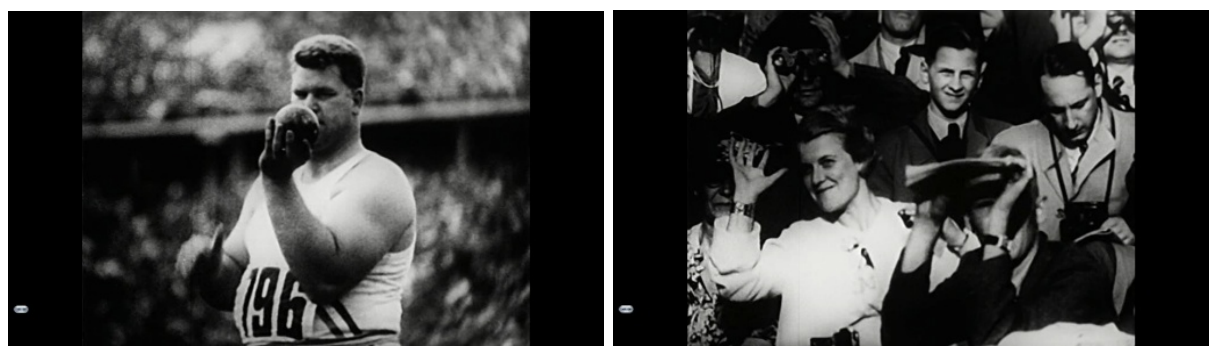

Figura 11: el humor en la prueba de lanzamiento de peso. 
Esta escena particular de Olympia queda en un apunte, en un detalle, de cómo el público se convierte en transmisor de emociones masivas. Y de cómo la masa se activa así como una matrix comportamental. Pero a lo largo de la película veremos todo tipo de gestos: uno típicamente italiano como ese "boh!" del chico con gorra que mezcla sorpresa y admiración, las jóvenes que animan, la niña con su padre protector, los soldados siempre en primera fila... de nuevo nos vemos tomado asiento y siendo parte de ese público en un plano subjetivo en este caso del público pero, en otras ocasiones, hasta alguno de los camarógrafos queda también retratado como parte de ese amplio público ferviente.
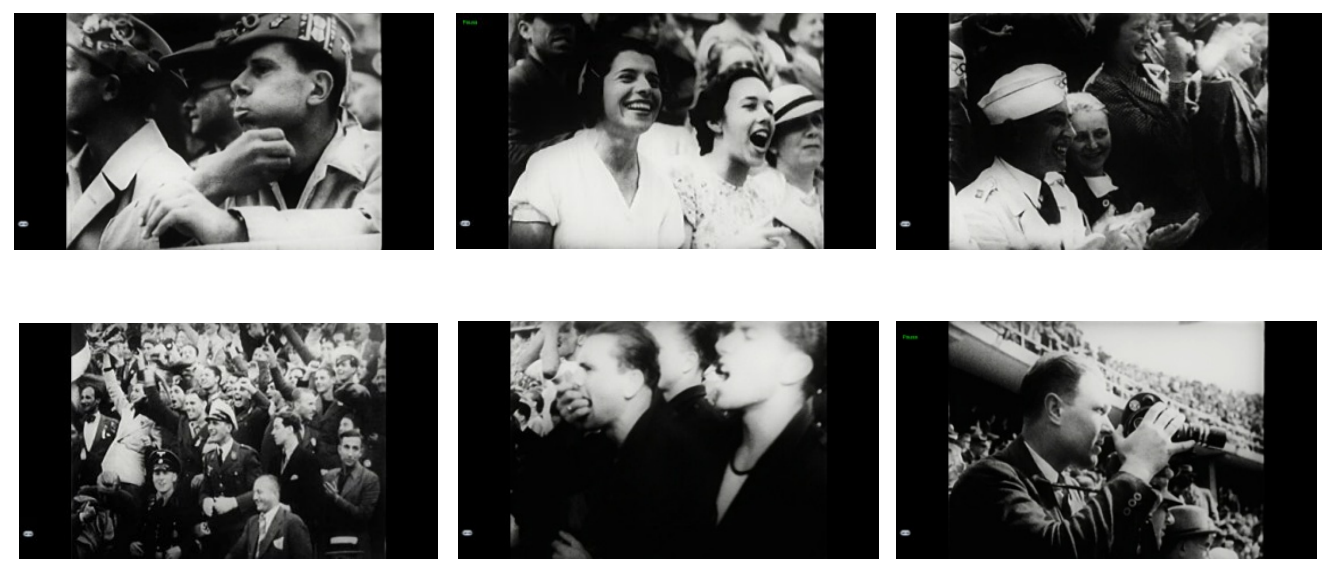

Figura 12: matices en la expresividad del público.

Un detalle que puede servir también para valorar el papel afirmativo del público es que nunca se le observa un gesto negativo o de reprobación. Es sintomático que puedan chillar, animar, sufrir, aplaudir, levantarse, apuntar, grabar, aplaudir... pero nunca mostrar desaprobación o rechazo. Es cierto que en ocasiones se advierten silbidos (prueba de Morris o de Owens) pero, o bien no vemos al público en ese momento (Owens), o estamos viendo al público con las banderas estadounidenses (Morris). Es decir, el público nunca se lamenta ni se queja. Se le podrá escuchar quejarse de forma indirecta o fugaz, en lo que parece más un fallo o un desajuste sonoro que tal vez sea síntoma de mínimos descuidos en la función expresiva del sonido, pero el público siempre aparece visualmente con actitud positiva, afirmativa, festiva incluso. A decir de Michaud (2009, p. 65),

los grandes estimulantes de la vida que eran esos espectáculos, conducidos por el orador con

un estilo extático vecino del expresionismo, constituían la experiencia narcisística esperada

tanto por el Führer como por su pueblo: experiencia de lo auténtico, del hic et nunc, de la unidad reencontrada del Volksgeist con su Volkskörper. Era la experiencia constitutiva del pueblo como sujeto.
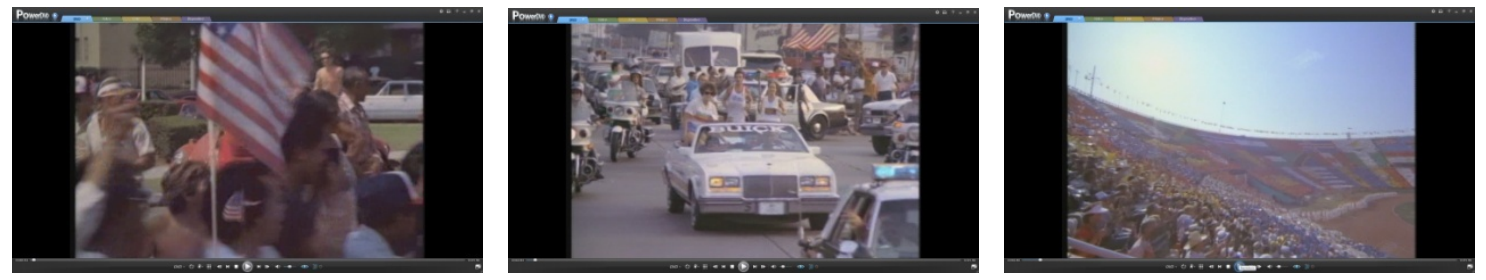

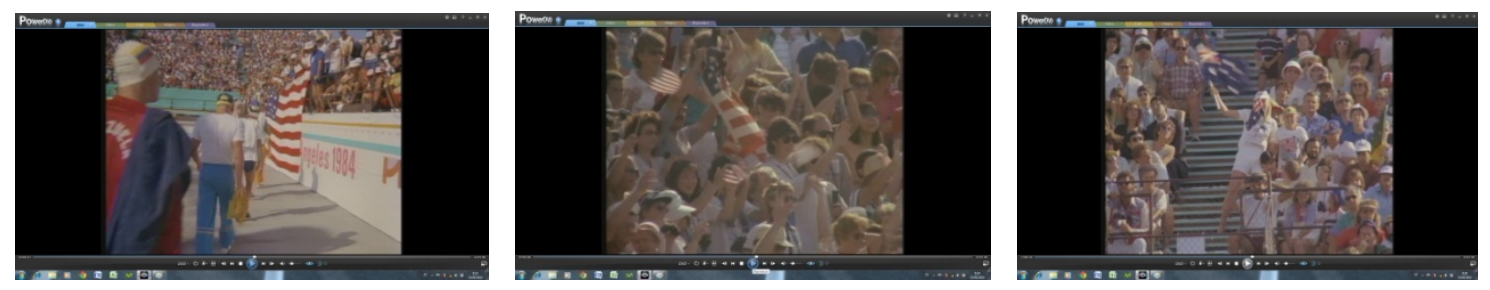

Figura 13: imágenes de 16 days of glory, película oficial de los Juegos Olímpicos de Los Ángeles (1984). Las primera tres imágenes corresponden al primer minuto de la película, una introducción donde abunda la presencia de la bandera. Las tres siguientes corresponden a la presentación de la prueba de natación (100 metros) que vencería el norteamericano Rowdy Gaines.

Los segundos Juegos Olímpicos que se celebraron en Los Ángeles supusieron la entrada del olimpismo en el mundo del espectáculo: se alquiló la antorcha a la que se le había puesto un simbólico taxímetro, costaba medio millón de pesetas esponsorizar cada kilómetro (Yagüe 1993: 433), fueron los juegos del boicot ruso y de las victorias abrumadoras de Carl Lewis. El relato oficial de los Juegos se llamó 16 days of glory y lo dirigió Bud Greenspan, quizá el mayor experto en cine documental olímpico de la historia (su serie The olympiad, que le valió un Emmy en 1976, se retransmitió en 80 países). Las tres primeras imágenes corresponden al primer minuto de la película. En esos 60 segundos hay 8 banderas americanas en 11 planos diferentes (aquí se citan 3). Las tres escenas siguientes corresponden a la prueba de natación donde ganó el estadounidense Gaines, construida, como se puede ver por las imágenes que prologan la prueba, sobre la identidad nacional. La bandera americana vincula al atleta con la grada y a la vez le enfrenta al nadador australiano, cuya bandera también enarbolan otros espectadores. Aquí las banderas ya no llevan cruces gamadas ni hay símbolos nazis pero hay más banderas americanas en el primer minuto de 16 days of glory que en todo el prólogo de la exaltación nazi de Olympia. Las banderas son la proyección de la identidad nacional y, al mismo tiempo, en un sentido más amplio, construyen un vínculo emocional con el público. Un público que como ya se ha planteado en esa refracción de espejos constituye el alter ego en la pantalla del espectador, sobre el que se está planteando también ese vínculo irracional de las banderas. Pasolini deja ya una advertencia (2015, pp. 41-42):

Nada es igual que un estadio lleno de gente: ni siquiera el gran público del cine, fraccionado

en mil salas y salitas, puede compararse con esa masa viva, rugiente $\mathrm{y}$, finalmente,

atormentadora de espectadores. Y en ningún otro ámbito se realiza una transferencia

semejante en el propio ídolo, como ideal realizado de uno mismo.

Es cierto que en la planificación de este film de Riefenstahl no se trata tanto de exaltarse ante la oratoria del Führer como ante un evento masivo en su presencia. Pero la fórmula de implicación y movilización de masas resulta análoga en todo caso. Desde el punto de vista de la masa, una de las funciones de ese líder mesiánico es la "sugestión de masa" como el propio Hitler establecía ya en Mein Kampf (Michaud 2009, p. 63) para acrecentar su poder y sus efectos sociopolíticos. Hitler exponía que lo importante de un mitin no era su contenido sino su éxito visible, reconocible. Dirá textualmente que lo necesario es desembarazarse de la idea de que las concepciones ideológicas podrían satisfacer a la multitud. "El conocimiento es para la masa una base tambaleante. Lo que es estable es el sentimiento, el odio..." (Michaud 2009, p. 64) y también la euforia con la victoria (como sucede en Olympia). El fascismo exhibía el poder para aumentar ese poder y esa confianza colectiva de masa, a la vez que se anticipaba con ello su poder proyectado hacia el futuro. El análisis 
fílmico puede mostrar que la función de sugestión masiva, en Olympia, no la cumple tanto el líder como el dispositivo de montaje y la planificación visual que la película propone como dispositivo de representación.

Esa expresión del poder, esa escenificación de la masa ya no meramente aclamando a su líder sino como una pauta general de comportamiento, como una fórmula conductual, es también un elemento de modernidad que ha dado continuidad al código fascista. Una imagen del público y la masa de este tipo, como diría Sloterdijk en un sentido más abierto, "ofrece la descripción más plausible a la vez que polemológica del comportamiento de las mayorías en las sociedades modernas" (2002, p. 57). De ahí que (como ha explicado Bauman 1998) modernidad y fascismo mantengan entre sí una relación pragmática, latente, que va más allá de los tópicos y esquematismos al uso cuando se aborda la temática del fascismo.

\subsection{Atletas}

Relata uno de los mayores conocedores deOlympia, Cooper C. Graham que la primera vez que vio la película de Riefenstahl, sin conocer mucho la historia de los Juegos, su impresión fue que los Estados Unidos habían ganado los Juegos, mientras fue Alemania quien (si se puntúan las medallas) ganaron holgadamente esta competición (2001, p. 255). De hecho, precisamente se convierte en uno de los argumentos esenciales para defender que es una obra de propaganda: "la película es peligroso por su aparente equidad, nunca a pesar de ella" (2001, p. 259). El análisis del film descubre en cambio un mensaje complejo y ambivalente. Un ejemplo es la figura de Hitler a quien ensalza pero también humaniza, a quien encumbra pero también desmonta, como si cada exaltación tuviera su disculpa. En este sentido, o bien la película que nos ocupa es una combinación dialéctica de documental y propaganda, o bien, si se la toma en clave únicamente propagandística, esta lectura llevaría a una corrección de la idea dominante o tradicional de propaganda, como ya propone Graham (2001, p. 251):

La definición más común (de propaganda) denota que un grupo trata deliberadamente y

conscientemente de cambiar las ideas de otro grupo. Si se asume esta definición y la versión

de Riefenstahl (siempre negó que fuera más que un documental), entonces los argumentos de

Riefenstahl son correctos. Esa definición excluye a este film de ser propaganda.

Esta complejidad de dimensiones y matices puede finalmente corroborarse atendiendo al tratamiento que la película dispensa a dos atletas americanos: Glenn Morris y Jesse Owens son indiscutiblemente los protagonistas de los Juegos de Berlín y deOlympia, al menos, en lo deportivo, pero también en lo extra-deportivo (Yagüe 1992, pp. 200-203).

Si se suman los minutos de la prueba de los 100 metros y el salto de longitud, éste sería el tercer bloque con más espacio de la primera parte. Owens es el único ganador que repite en la película (en la realidad la holandesa Mastenbroek también ganó 4 medallas pero prácticamente se obvia). En cuanto al decatlón de Morris, ésta es, sólo después del maratón, la prueba con más espacio de toda la película. En la pista nadie iguala a Morris y a Owens, plano a plano, ni siquiera Hitler obtiene tanto espacio, aunque como ya se ha dicho Hitler tiene muchas más expresiones y emociones de las que transmiten estos dos deportistas. No obstante, no es sólo una cuestión de tiempo en escena sino también de cómo se está ahí. Ningún atleta se recrea y sonríe directamente ante la cámara como Owens. Y tampoco en ninguna otra prueba, el locutor nos da pistas de la victoria, como ocurre con 
Morris, y mucho menos la cámara se recrea en personalizar y dar tantos planos centrados en un deportista como en el caso del americano.
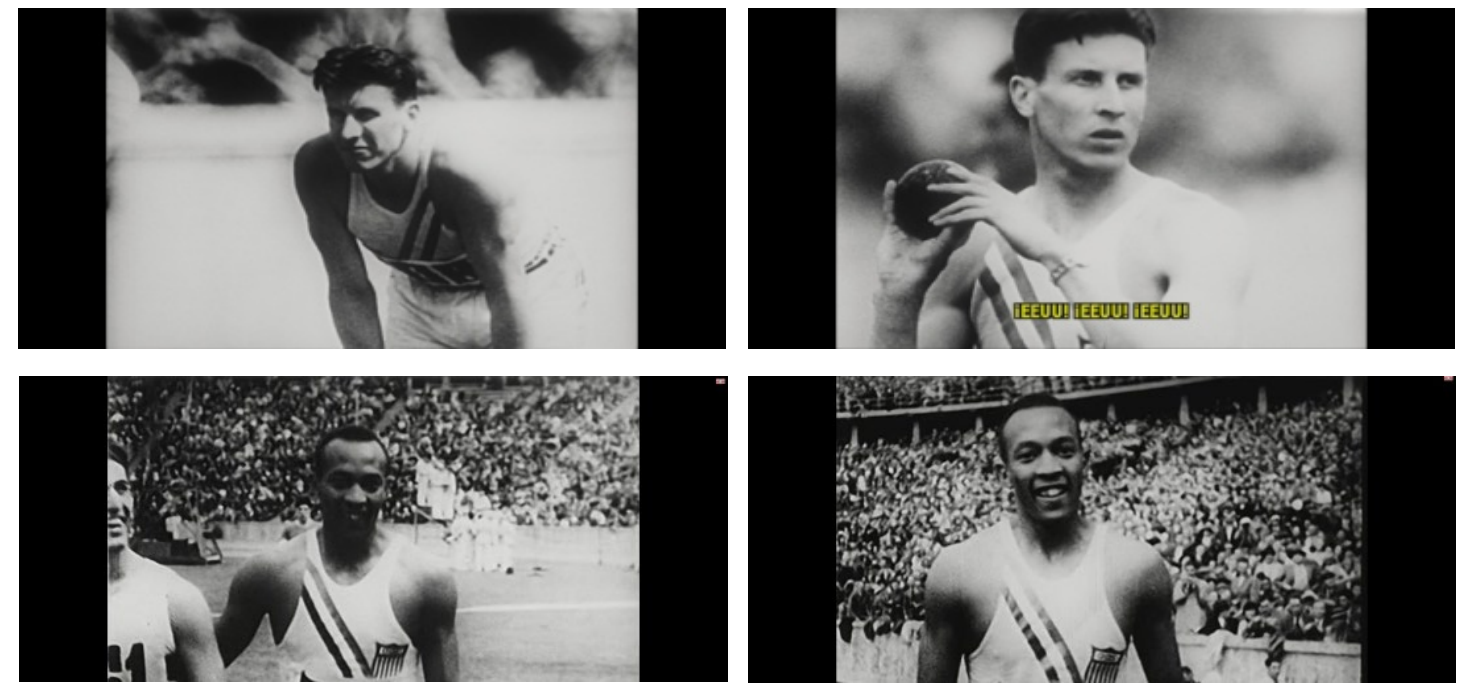

Figura 14: protagonismo de Owens y Morris.

En el caso de Morris y la prueba de decatlón, se suma el hecho de que la victoria de los norteamericanos es aplastante. Los deportistas americanos de la disciplina, quizá porque era el único país con especialistas, ganan en todas las pruebas. En las de pista (vallas o 400 metros) lo hacen además a una considerable distancia con lo que los planos suelen mostrar a Morris llegando sólo a la meta y la emoción no es mucha. Morris, ya campeón, bate incluso en la última prueba a Huber, el participante alemán, con lo que la victoria americana implica también la derrota alemana y se escuchan pitos. Lo mismo sucede con Owens quién en la prueba del salto de longitud se impone a Long, alemán y ante los ojos de un Hitler que ha ido a ver cómo Owens era derrotado y es testigo justo de lo contrario.

Downing expone ante el tratamiento que Owens recibe en la película que Riefenstahl contravino los deseos nazis con la celebración de los logros del atleta afroamericano. Las victorias del "negro de Alabama" eran toda una "afirmación política en la Alemania Nazi" (Downing 2012, p. 82). El autor recuerda además que, mientras tanto, el ministerio de propaganda alemán había prohibido llevar y publicar el listado de victorias por países e insistía en que las victorias eran algo personal. Así mismo, estaba prohibido publicar también los logros de los atletas negros (Downing 2012, p. 89). Mientras tanto, la película de Leni Riefenstahl se convierte en una exhibición de los logros no sólo de Owens sino también de Morris.
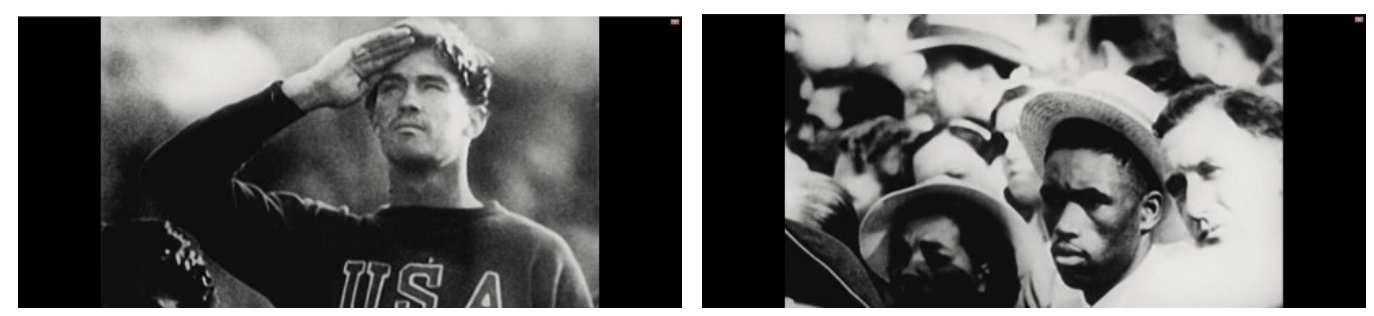

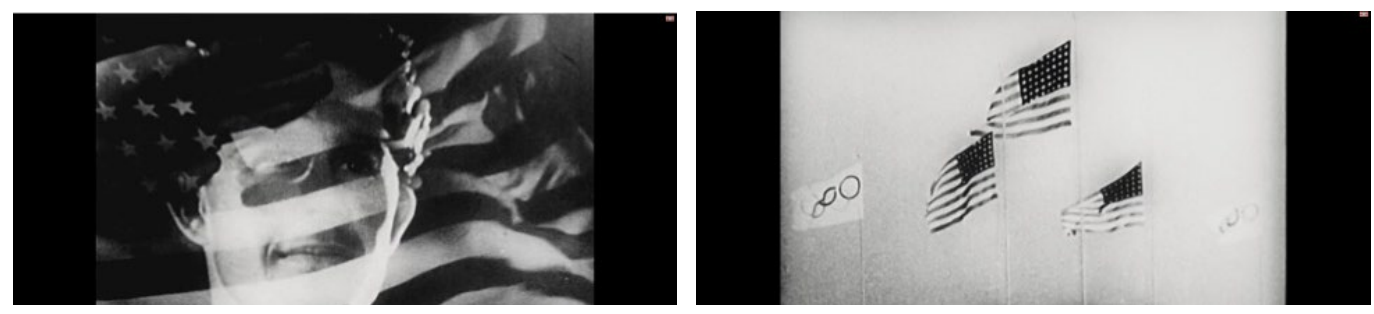

Figuras 15: victorias norteamericanas.

No se trata sólo de una prueba o una imagen particular. La cámara muestra el símbolo patriótico estadounidense por excelencia, la bandera, que ondea en los tres mástiles tras la prueba de salto de altura masculino. Se busca en el público al público negro de la prueba de los 110 metros vallas y se cierra la escena con el saludo olímpico del atleta americano coronado de laurel. La final del emocionante salto con pértiga se cierra con el fundido de la bandera de los Estados Unidos sobre la cara del vencedor. Olympia podría haberse ahorrado muchas de estas escenas. El ejemplo quizá más evidente es el fundido sobre la cara del vencedor del americano Meadows. Ya no sólo es que se elija esa imagen cerrada de la cara del vencedor sino que, además, se emplea un recurso de montaje para que se evidencie al deportista y a su país. ¿Pero cómo encaja esto con una película que debía exaltar el fascismo?

Olympia plantea una visión marcadamente nacionalista de los Juegos Olímpicos. Esto no sólo afecta a los símbolos de la Alemania Nazi que serán enarbolados ante cada victoria sino que el mismo lenguaje servirá para relatar el resto de victorias de los otros países. No es casual que, cuando intervenga un atleta de la India, entre el público aparezcan hindúes, que los japoneses acompañen las victorias de las nadadoras compatriotas suyas o que sean los militares alemanes los que abracen al soldado que acaba de ganar la Gran Copa de las Naciones para Alemania. Esas identificaciones hacen de Olympia como una película explícitamente nacionalista en tanto la identidad nacional se trabaja como un principio rector del montaje y el ritmo compositivo. Graham expone que precisamente "con su equidad con todas las naciones, el film desarma al criticismo" y recuerda que uno de los mayores propósitos del film era representar la amabilidad y buena voluntad de Alemania" (entonces despertaba todos los recelos) (Graham 2001, p. 255).

Se podría decir que, por encima de Alemania o de Hitler, o de las victorias está el mensaje. Cuando se piensa en la propaganda fascista clásica se piensa en la exaltación absoluta pero Olympia está lejos de ser una loa irracional del fascismo y su líder. Más bien y, en casos concretos como se ha visto, se trataría aquí de desmontar la imagen de Hitler como líder imperturbable y distante para evitar ese temor que despierta el nazismo fuera de las fronteras. La identificación del público con sus atletas o la exuberancia de la descripción de las victorias americanas no son paradójicas si se piensa en una concepción nacionalista del mundo. Fomentar esa competencia, matizar la idea de la Alemania Nazi dentro de un código de representación abierto, son algunas de las paradojas que muestran la complejidad concreta de este mensaje audiovisual pero que también permiten replantear el mito nazi. El código representativo, así, se localiza en un tratamiento propagandístico complejo, renovado, autocrítico. Esta apertura o autocorrección de la propaganda tiene que ver con la vocación documental del film. En este punto, la comprensión de Olympia se vuelve así mismo compleja por esta relación dialéctica entre documental y propaganda:

En el fondo, sobre el cine documental todavía se cierne una sospecha: la de que pudiera no

tratarse de verdadero cine, porque no hace soñar a las masas (¿de verdad alguien va al cine 
para ver un documental?) (...) Y, pese a todo, (...) sólo existe una diferencia fundamental entre un paisaje filmado en una ficción y un paisaje filmado en un documental: la elección de un encuadre, una duración, una ubicación dentro de un montaje y, a fortiori, dentro de un relato; es decir, una diferencia de forma y no de naturaleza. (Breschand 2004, p. 4)

Si el documental "no hace soñar a las masas" podría entonces ser considerado de hecho como una suerte de anti-propaganda. Sin embargo, y a la vez, en la medida en que documental y ficción están interconectados necesariamente (por una diferencia no de forma pero sí de naturaleza) podría afirmarse entonces que documental, propaganda y ficción pueden dialogar en la práctica. El componente de documental abre el paso en Olympia a la irrupción de la ficción y, con ésta, entrarían en la película (como si dijéramos, por vía indirecta) elementos narrativos y visuales que puedan complementar un enfoque propagandístico volviéndolo más dinámico, flexible y próximo. Esta dialéctica acercaría Olympia a películas olímpicas posteriores. Y, a la inversa, esta misma reflexión aproximaría la hipótesis de que dichas películas o retransmisiones contemporáneas post-fascistas pudieran estar reproduciendo recursos de propaganda compartidos con los propios del contexto fascista. Un ejemplo son las imágenes que se citan a continuación de una de las películas más recientes del olimpismo. First (2012) describe lo sucedido durante ese verano en los Juegos Olímpicos de Londres. Ya no sólo son contigüidades visuales sino recursos como la resignificación de símbolos olímpicos (antorcha) la exaltación e individualismo de los atletas, su transformación en personajes que ya se advierte con Owens y la referencialidad política.
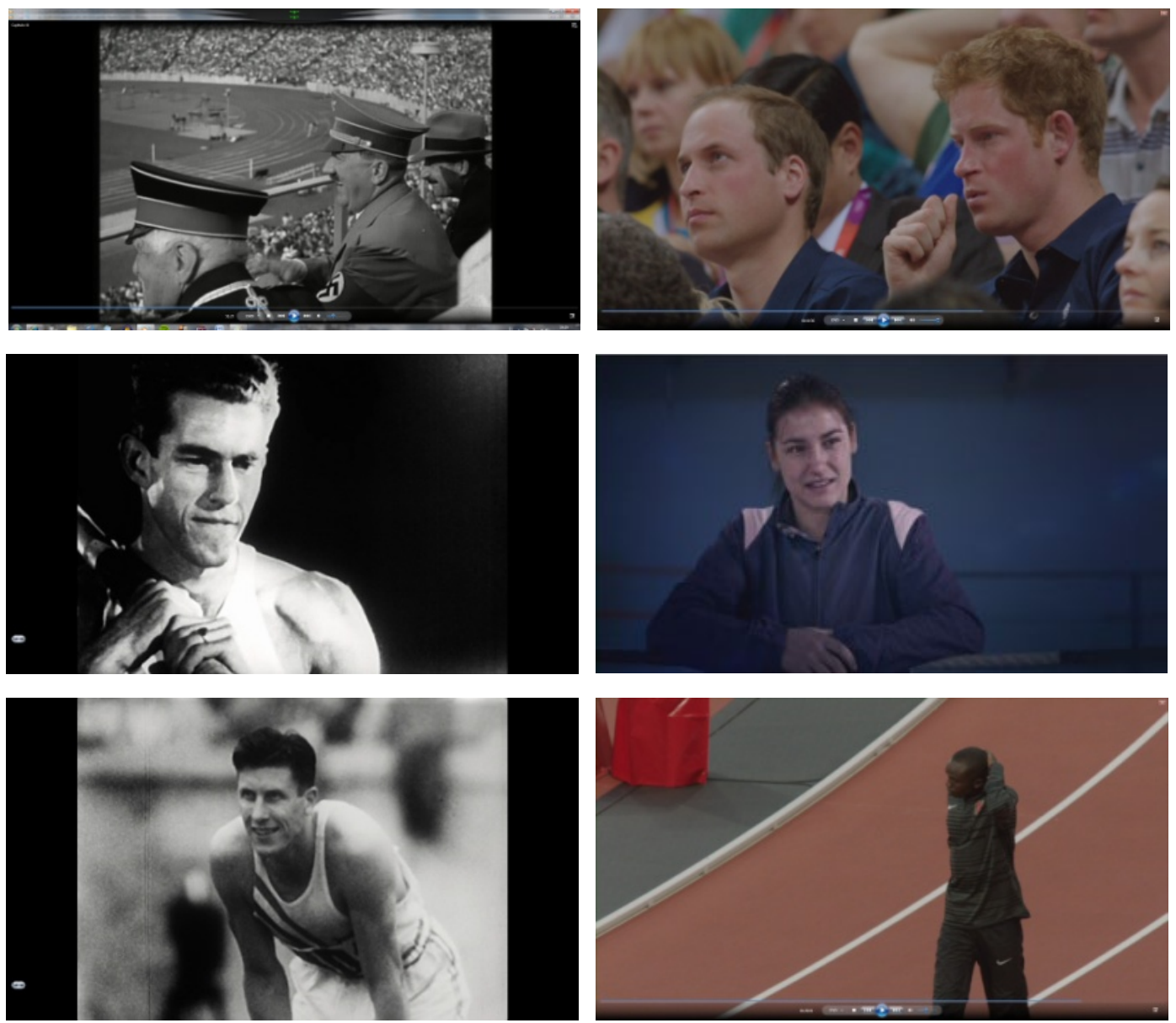

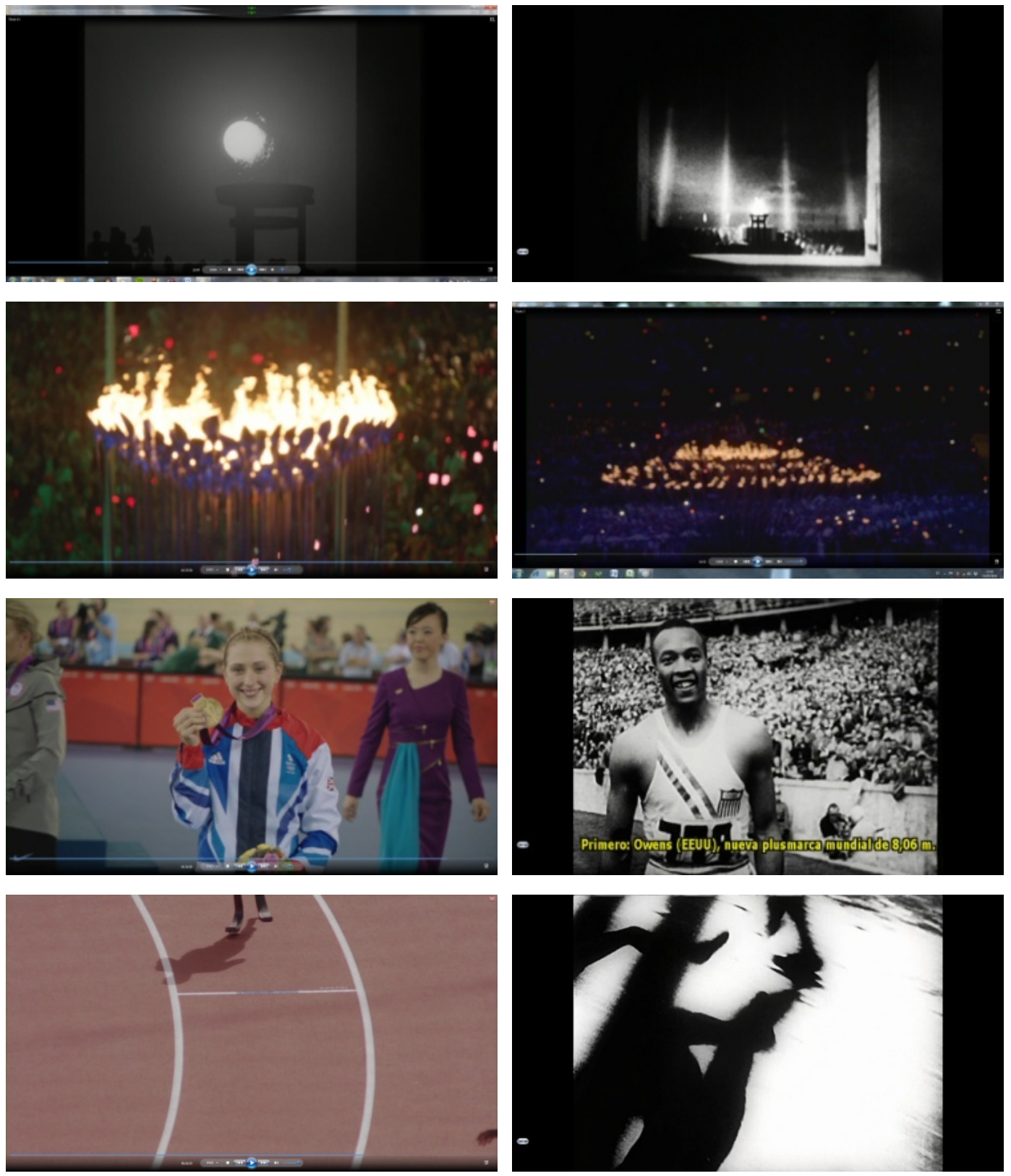

Figura 16: paralelismo entre las imágenes de Olympia (1938) y First (2012), la película oficial de los Juegos Olímpicos de Londres. Se compara la imagen de Hitler y la de los príncipes herederos. Se compara la presentación de los atletas y el simbolismo de la antorcha, la sonrisa de Owens y el guiño a las imágenes del maratón en la aparición de Pistorious.

Ese recurso al arte para explicar la política y para que asuma sus características debe aplicarse también a la capacidad para dirigirse a las emociones que posee el arte. Eso es algo que puede verse en la película donde el nacionalismo se logra por la vía de la victoria y la identificación con el deportista, muchas veces, por medio del ganador. Esa capacidad ya nunca se descabalgará de los discursos modernos de la política. Por otra parte, la sugestión de las masas no choca con el individualismo. Otro de los elementos olvidados de ese mito nazi es la exaltación del logro individual. La masa es la que otorga autoridad y respalda la decisión pero el héroe siempre es individual. El salvador siempre es uno. A pesar de la presencia y los matices del público no deja de ser un coro plural que empatiza o refleja lo que ocurre en la pista. Los protagonistas de Olympia son 
Hitler, Owen, Morris, pero también el público de masa, y la mirada individualiza a cada uno de ellos. Son ellos los que miran directamente al espectador.

Esta teoría de la autoproducción que el propio Hitler mismo se aplicaba proviene claramente del Romanticismo (Michaud 2009, p. 62). Con ese movimiento entronca también el primer cine de Riefenstahl, el llamado "cine de montaña", donde mezclaba lo épico de una naturaleza desbocada con héroes individuales obligados a luchar contra la sociedad o las propias fuerzas de la naturaleza (sirva como ejemplo La luz azul (1932), dirigida y protagonizada por Riefenstahl, cuya protagonista es una ermitaña que vive en una cueva de piedras preciosas finalmente arrasada por el pueblo). A su vez esta teoría de la autoproducción enlaza con un concepto de individualismo que está en el centro del imaginario nazi y que se sublima en los logros del deporte. El deporte funciona no tanto como vía de escape como, más activamente, de un modo ni inofensivo ni inerme, proyector masivo de una gloria ideal, atemporal, que niegue por un momento la catástrofe de lo real. El deporte tiene además la capacidad de reunir la sugestión de la masa con la visión individualista de la realidad.

\section{Conclusiones: Hacia la actualidad, desde el presente}

En conclusión, el estudio fílmico de Olympia (1938) se inserta en una serie de marcos críticos tanto en lo tocante a su relación con el contexto histórico del momento como con otros textos fílmicos coetáneos y posteriores. Así pues, el análisis requeriría metodológicamente de la consideración de hipótesis de trabajo amplias y complejas. Estas hipótesis críticas entran en una relación a modo de círculos concéntricos que, más concretamente, serían fundamentalmente tres:

a) La relación del texto fílmico con el imaginario fascista. A pesar de los vínculos fácticos entre Leni Riefenstahl y el régimen nazi el análisis audiovisual detecta rasgos formales en el film Olympia que matizan la idea de una relación mecánica entre texto y contexto. De hecho, algunos de esos rasgos a la hora de representar las figuras del líder, atletas o público de masa pueden detectarse en otras películas olímpicas realizadas en contextos distintos y en principio alejados del contexto nazi o fascista clásico.

b) La relación dialéctica entre códigos propagandísticos, estéticos, documentales y ficcionales. La investigación de los resortes formales, ideológicos y (con) textuales parece indicar la necesidad de no limitar el enfoque analítico a géneros de representación específicos sino, más bien, de abrir e interconectar códigos de representación siguiendo una lógica multidimensional, caleidoscópica. Esa lógica no descarta factores estéticos ni propagandísticos ni documentales sino que, de forma dialógica, los articula llevando cada uno de esos factores fuera de sí mismo, hacia un espacio sintagmático y paradigmático nuevo y singularmente poderoso.

c) La relación de la política comunicativa fascista con otras políticas comunicativas contemporáneas. En última instancia, esta hipótesis se apoya en la premisa de que "el fascismo contemporáneo -o postfascismo postmoderno- puede llegar a ser incluso fascismo democrático" (Querol 2015, p.195). El análisis se vuelve así polémico o polemológico por cuando recupera aportaciones críticas previas (Adorno/Horkheimer, Arendt, Pasolini, Sontag, Pasolini, Stanley, Amery...) y las resitúa en una constelación actualizada de argumentos y elementos coherentes entre sí.

En el terreno de las grabaciones audiovisuales y retransmisiones deportivas en la época global es evidente, como indicaba en su momento Pasolini (2015, p. 104), que "ya hace demasiado tiempo que el deporte es espectáculo, y toda la organización deportiva está a favor del espectáculo". El deporte, como espectáculo audiovisual global, no ha hecho más que vivir un ascenso imparable en las últimas décadas: 
Hoy, poco a poco, nada que sea físico es necesario, dado que la máquina lo ha sustituido todo.

Así, frente a la necesidad, el deporte se ha convertido lentamente en un puro hecho higiénico y solo sobrevive, diría, porque desahoga ciertos instintos agresivos y competitivos, de dominación, que en el hombre moderno todavía no se han apagado. De modo que se ha convertido en espectáculo por la exigencia de las masas ingentes que, sin duda, no aman la brevedad exquisita de un endecasílabo. (Pasolini, 2015, p. 106)

La conexión entre espectáculo deportivo y sociedad de consumo se puede asociar, de un modo actualizado, a los tradicionales recursos de la propaganda en la medida en que el fascismo se haya renovado en nuevas formas de influencia. Siguiendo a Pasolini, "el verdadero fascismo es lo que los sociólogos han llamado alegremente sociedad de consumo. Una definición que parece inocua, mera indicación. Pero no es así. (...) Los resultados de esta despreocupada sociedad de consumo son los de una dictadura" (2009, p. 276). Lo que Pasolini llamara metafóricamente "la desaparición de las luciérnagas", en suma, podría entonces relacionarse con la supervivencia de problemáticas supuestamente superadas así como con el reto de nuevas formas poéticas y políticas de entender el mundo (Didi-Huberman 2012).

Ya Sontag expuso en su crítica a Riefenstahl que tanto en el fascismo como en el comunismo "se hace un despliegue público de la libertad, en el drama del líder y el coro” (Sontag 2007, p. 101). ¿Podría este despliegue haber impregnado el modelo de representación audiovisual de las masas en contextos democráticos o liberales? Sontag cree que el arte fascista está difícilmente confinado a los trabajos etiquetados como tales o bajo gobiernos abiertamente fascistas (menciona Fantasía de Disney como ilustración de este problema). Plantea incluso cómo el arte fascista y comunista comparten características, como si existiera lo que Pasolini llamaba "fascismo de izquierdas" (Pasolini 2002, p. 39). El rasgo transversal o común podría ser "la predilección por lo monumental y por la obediencia de las masas al héroe" (Sontag 2007, p. 100) pero también, al mismo tiempo, la tendencia a la idealización de los cuerpos sustentaría en el imaginario fascista "una estética utópica de la perfección física" (2007, p. 101). Lo interesante para Sontag, en suma, es que durante el nazismo y el comunismo la política totalitaria se apropió de la retórica del arte y de los códigos dominantes en la comunicación de masas, así como para Pasolini (2009) el capitalismo consumista expandiría una especie de nuevo fascismo. La imagen sea quizá sólo la huella más evidente de una continuidad, de un poso ideológico compartido, de rasgos transversales, tendencias comunes, un imaginario compartido o simples apropiaciones. Otro ejemplo lo pone Michaud (2009, p. 343) citando a Canetti a propósito de la coerción que supone el afán de superación, un rasgo nazi que le permite conectar con las inseguridades y el inconsciente de la sociedad actual. Elias Canetti lo había notado:

Cada una de sus empresas, pero también de sus deseos más profundos, están dictados por la coerción de la superación: se podría incluso calificarlo de esclavo de la superación. Pero en eso no está solo. Si se debía calificar con un rasgo la esencia de nuestra sociedad sólo se podría encontrar éste: la coerción de la superación. 
Estas apropiaciones podrían confirmar la hipótesis crítica de Bauman (1998) y otros analistas del fenómeno fascista a lo largo del siglo XX. La pregunta es, pues, si esa apropiación no desdibujó en cierto modo los supuestos límites entre regímenes de representación simbólica (arte, propaganda, espectáculo...) y entre regímenes económico-políticos (fascismo, comunismo, socialdemocracia...). Hablar sobre el sentimentalismo del líder y la embriaguez de la masa, como es tópico en los debates sobre el fascismo clásico, debería conducir a ver cómo los mecanismos del fascismo clásico calaron en formas posteriores de entender la comunicación y la política. No en vano, esta difuminación de los límites es un fenómeno multidimensional cuyas huellas pueden haber seguido dándose en la era post-fascista. Sugiere Klemperer que "la característica determinante de la corriente espiritual más alemana se llama: ausencia de límites" (Klemperer 2007, p. 208). Pero este rasgo ideológico podría ser contrastado y evaluado más allá del período totalitario que se reconoce convencionalmente como tal en la historia contemporánea.

\section{Referencias bibliográficas}

Adorno, T. y Horkheimer, M. (2003). Dialéctica de la Ilustración. Trotta.

Amery, C. (2002). Auschwitz, ¿comienza el siglo XXI? (Hitler como precursor). Turner / FCE.

Arendt, H. (1987). Los orígenes del totalitarismo (3). Alianza Editorial.

Arendt, H. (2013). Eichmann en Jerusalén. Debolsillo.

Baceiredo, R. (2016). Capitalismo e fascismo. Eusein.

Bauman, Z. (1998). Modernidad y Holocausto. Sequitur.

Benjamin, W. (2012). La obra de arte en la época de su reproductibilidad técnica, en Obras (Libro I. Vol. 2), (pp. 49-85). Abada Editores.

Breschand, J. (2004). El documental (La otra cara del cine). Paidós.

Debord, G. (1999). La sociedad del espectáculo. Pre-Textos.

Didi-Huberman, G. (2012). Supervivencia de las luciérnagas. Abada Editores.

Downing, T. (2012). Olympia. Palgrave Macmillan.

Graham, C. (2001). Leni Riefenstahl and Olympia. The Scarecrow Press.

Gubern, R. (2004). Patologías de la imagen. Anagrama, colección Argumentos.

Klemperer, V. (2007). LTI: La lengua del Tercer Reich. minúscula.

Kracauer, S. (1985). De Caligari a Hitler (Una historia psicológica del cine alemán). Paidós.

Krüger, A. \& Murray, W. (2003). The nazi olympics. Sport, Politics and Appeasement in the 1930s. University of Illinois press.

Lozano, Á. (2010). El Holocausto y la cultura de masas. Melusina. 
RLCS, Revista Latina de Comunicación Social, 75, 69-96

[Investigación] DOI: 10.4185/RLCS-2020-1417| ISSN 1138-5820 | Año 2020

Méndez Rubio, A. (2017). ¡Suban a bordo! Introducción al fascismo de baja intensidad. Grupo5.

Michaud, E. (2009). La estética nazi (Un arte de la eternidad). Adriana Hidalgo.

Negus, K. (1996). Popular Music in Theory (An Introduction). Polity Press: Cambridge.

Pasolini, P. P. (2002). Transhumanar y organizar. Visor.

Pasolini, P. P. (2009). Escritos corsarios. Ediciones del Oriente y del Mediterráneo.

Pasolini, P. P. (2015). Sobre el deporte. Contraediciones.

Payne, S. G. (2014). El fascismo. Alianza Editorial.

Paxton, R. O. (2005). Anatomía del fascismo. Península.

Pizarroso, A. (1990). Historia de la propaganda. Eudeba.

Pizarroso, A. (2005). Nuevas guerras, nueva propaganda. Cátedra.

Querol, J. M. (2015). Postfascismos (El lado oscuro de la democracia). Díaz \& Pons.

Rentschler, E. (2002). The ministry of illusion: Nazi cinema and its afterlife. Harvard University Press.

Sloterdijk, P. (2002). El desprecio de las masas. Pre-Textos.

Sontag, S. (2007). Fascinante fascismo, en Bajo el signo de Saturno, (pp. 81-116). Debolsillo.

Vidal González, R. (2006). La actividad propagandística de Walt Disney durante la Segunda Guerra Mundial. Publicaciones Universidad Pontificia.

Yagüe, F. (1992). Historias de las Olimpiadas. Plaza y Janés.

\section{AUTORES:}

\section{Antonio Méndez Rubio}

Filología, Traducción y Comunicación. Universitat de València. España.

En la actualidad es Profesor Titular de Universidad del área Teoría de los de los Lenguajes y Ciencias de la Comunicación en la Universitat de València. Doctor en Filología Hispánica y premio extraordinario de doctorado, es también licenciado en Comunicación. Profesor Visitante de la Duke University, (EE.UU) y la Universidad de Virginia (EE.UU.) ha sido docente también en el ADEIT de la Universidad de Valéncia, la Universidad del País Vasco/EHU y actualmente es profesor del máster "Interculturalidad y derechos humanos" de la universidad Pablo Olavide de Sevilla. Ha trabajado en los proyectos de investigación Immigration, culture et communication en Méditerranée (Institut Maghreb-Europe/Université Paris 8); Prácticas, discursos y representaciones en imaginarios y procesos de desarrollo (Proyecto de Innovación Educativa) de la Universitat de València; La cultura como recurso de desarrollo (Ministerio de Ciencia e Innovación). Ha publicado los libros «iSuban a bordo! Introducción al fascismo de baja intensidad» (2017), «La desaparición del exterior» (2012), 
«Perspectivas sobre comunicación y sociedad» (2004), «La apuesta invisible» (2003), «Poesía 68» (2003), «Encrucijadas (Elementos de crítica de la cultura)» (1997), «Hacia una teoría crítica de la cultura» (1999) o «El conflicto entre lo popular y lo masivo» (1995). Ha sido miembro del Consejo Académico del Instituto de Cultura Gitana, del Consejo Científico del Observatorio de Estudios Culturales de la Universidad Internacional Menéndez Pelayo y ha formado parte del Comité Científico de la revista Perspectivas de la Comunicación (Universidad de la Frontera, Temuco Chile. Ha dirigido las II Jornadas De Actualidad Crítica del UVEG-Servei d'Extensió Univeristària y codirigido el Seminario Iberia 2002: Globalización y espacio urbano (Las nuevas culturas metropolitanas) para el Duke Center for Hispanic Studies/CEU San Pablo.

Antonio.Mendez@uv.es

Orcid ID: https://orcid.org/0000-0001-8847-0741

\section{Javier Lizaga Villarroya}

Doctorado. Universitat de València. España.

En la actualidad es Coordinador de Informativos de la delegación de Teruel de Aragón TV, televisión pública de la Comunidad Autónoma de Aragón. Doctor en Comunicación por la Universitat de València. Máster en Interculturalidad y Políticas Comunicativas por dicha universidad y máster en Educación, Comunicación y Cultura por la Autónoma de Barcelona. Ha trabajado en Onda Cero, Cadena Ser, Heraldo de Aragón y TVE. Investigador sobre el fascismo, la propaganda y el deporte, tema sobre el que ha realizado su tesis doctoral. Ha defendido ponencias en el VI Congreso de La Latina de Comunicación Social (2014), en el XV Congreso de Periodismo de Huesca (2014), II Congreso Relatos de la Crisis de Valparaíso Chile y V Congreso de la Imagen, celebrado en Berlín (2014). Ha publicado en la Revista Faro y en la revista internacional de la imagen y colabora con los Cuadernos de cine Cabiria. Ha sido parte del consejo de revisión de Fonseca Journal Communication de la Universidad de Salamanca y Comité de pares para la revista Faro de la Universidad de Playa Ancha.

jlizaga@hotmail.com

Orcid ID: https://orcid.org/0000-0003-2619-5603 